\title{
Conformational behaviour of biologically active ferulic acid derivatives
}

\author{
Rita Calheiros ${ }^{a}$, Fernanda Borges ${ }^{\mathrm{a}, \mathrm{b}}$, M. Paula M. Marques ${ }^{\mathrm{a}, \mathrm{c}, *}$ \\ ${ }^{a}$ Research Unit "Molecular Physical-Chemistry", University of Coimbra, 3004-535 Coimbra, Portugal \\ ${ }^{b}$ Organic Chemistry Department, Faculty of Pharmacy, University of Porto, 4050-047 Porto, Portugal \\ ${ }^{\mathrm{c}}$ Biochemistry Department, Faculty of Sciences and Technology, University of Coimbra, Ap. 3126, 3001-401 Coimbra, Portugal
}

\section{A R T I C L E I N F O}

\section{Article history:}

Received 29 June 2009

Received in revised form 20 July 2009

Accepted 21 July 2009

Available online 28 July 2009

\section{Keywords:}

Ferulic acid

Hydroxycinnamates

Conformational analysis

Internal rotations

DFT calculations

\begin{abstract}
A B S T R A C T
The conformational behaviour of several biologically relevant hydroxycinnamic systems - ferulic acid and its methyl, ethyl, propyl and butyl esters - was studied by quantum mechanical calculations, at the DFT level. A full geometry optimisation was carried out, as well as a Fourier analysis of the main internal rotations within these molecules. The geometrical preferences of these compounds result from a balance between the stabilising resonance and hydrogen bonding effects and the destabilising non-bonding repulsions, the most stable conformers displaying an s-cis conformation and hydroxyl/methoxyl substituent groups coplanar to the aromatic ring. The results thus obtained allow a better understanding of the well recognised in vitro and in vivo antioxidant and growth-inhibiting properties of this type of phenolic systems.
\end{abstract}

(c) 2009 Published by Elsevier B.V.

\section{Introduction}

Hydroxycinnamic acids and hydroxycinnamates have received particular attention in the past 10 years, since their potential health benefits have been discovered, namely in the prevention of several human diseases related with the oxidative stress [117]. They are an integral part of a diet rich in fruit, vegetables and beverages and may scavenge free-radical oxygen species both in vitro and in vivo [18-20]. Although, apart from the recognised antioxidant activity, hydroxycinnamic acids and derivatives, can act in vivo by triggering gene induction/repression via intracellular signalling network molecules [1,21-26].

Ferulic acid (FA), which corresponds to a monohydroxylated cinnamic acid, and its ester derivatives possess distinct structural motifs that contribute to their biological activity: the presence of electron-donating substituent groups in the aromatic ring (hydroxyl and/or methoxyl); the acid or ester moiety with an adjacent unsaturated $\mathrm{C}=\mathrm{C}$ double bond, providing additional sites of attack for free radicals; and the carboxylic group, acting as an anchor to the lipid bilayer and the ester group, thus contributing to the significant lipophilicity of these molecules. In addition, the biological efficacy of this kind of phenolic systems is expected to be dose- and structure-dependent, which renders the studies on their structural preferences, essential for the understanding of their multifunctional biological actions.

\footnotetext{
* Corresponding author. Address: Research Unit "Molecular Physical-Chemistry", University of Coimbra, 3004-535 Coimbra, Portugal. Tel./fax: +351 239826541.

E-mail address: pmc@ci.uc.pt (M.P.M. Marques).
}

The present work aims at establishing the principal stabilising factors that rule the structural features of FA and its ester derivatives, using quantum mechanical (QM) calculation, at the Density Functional Theory (DFT) level. A complete geometry optimisation was performed for FA and methyl, ethyl, propyl and butyl ferulates (MF, EF, PF and BF, respectively), yielding all their lowest energy geometries. The energy barriers for the several internal rotations within the molecules were also calculated, and their Fourier profile was obtained.

\section{Computational methods}

\subsection{Quantum mechanical calculations}

The QM calculations were performed, using the GAUSSIAN $03 \mathrm{~W}$ computational package [27], with the GaussView interface program [28]. The Density Functional Theory (DFT) approach was applied, since it is a good compromise between accuracy and computational time and ensures a precise description of electronic correlation. The widely used hybrid method denoted by B3LYP, which includes a mixture of HF and DFT exchange terms and the gradient-corrected correlation functional of Lee, Yang and Parr [29,30], as proposed and parameterised by Becke [31,32] was employed, along with the standard valence double-zeta basis set 6-31G of Pople and co-workers [33], supplemented by a set of $d$ and $p$ polarisation functions $[34,35]$.

For each compound studied, the molecular geometries were fully optimised without applying any symmetry restrictions up 
to convergence, using the Berny algorithm in redundant internal coordinates [36]: the bond lengths to within ca. $0.1 \mathrm{pm}$ and the bond angles to within $c a .0 .1^{\circ}$. The final root-mean-square gradients were always less than $3 \times 10^{-4}$ hartree.bohr $^{-1}$ or hartree.radian $^{-1}$. The harmonic vibrational frequencies were also calculated, in order to confirm the convergence to minima in the potential-energy surface and to introduce the zero point vibrational energy (ZPVE) correction to the conformational energy.

Quantitative potential-energy profiles for rotation around different bonds within the molecule were obtained, scanning each fixed torsional angle $(\theta)$ by increments of $15^{\circ}$ or $30^{\circ}$. All remaining geometrical parameters were optimised at the B3LYP/6-31G(d,p) level of calculation. The relative energies of the rotamers were fitted using least-squares Fourier-type functions (Eq. (1)).

$V(\theta)=\sum_{n=1}^{4} \frac{1}{2} V_{n}[1-\cos (n \theta)]$

The parameters $V_{n}$ correspond to potential-energy relative to a reference value $[37,38]$ (where the subscript denotes the fold periodicity).

\section{Results}

\subsection{Geometry optimisation}

A complete geometry optimisation was carried out for ferulic acid (FA) and methyl (MF), ethyl (EF), propyl (PF) and butyl (BF) ferulates, always considering the trans isomer $\left(\theta\left(C_{3}-C_{9}-C_{10^{-}}\right.\right.$ $\left.C_{11}\right)=180^{\circ}$ ) (Fig. 1). For each of these compounds, the geometries and relative energies were obtained for the distinct calculated conformers (Figs. 2-6).

a
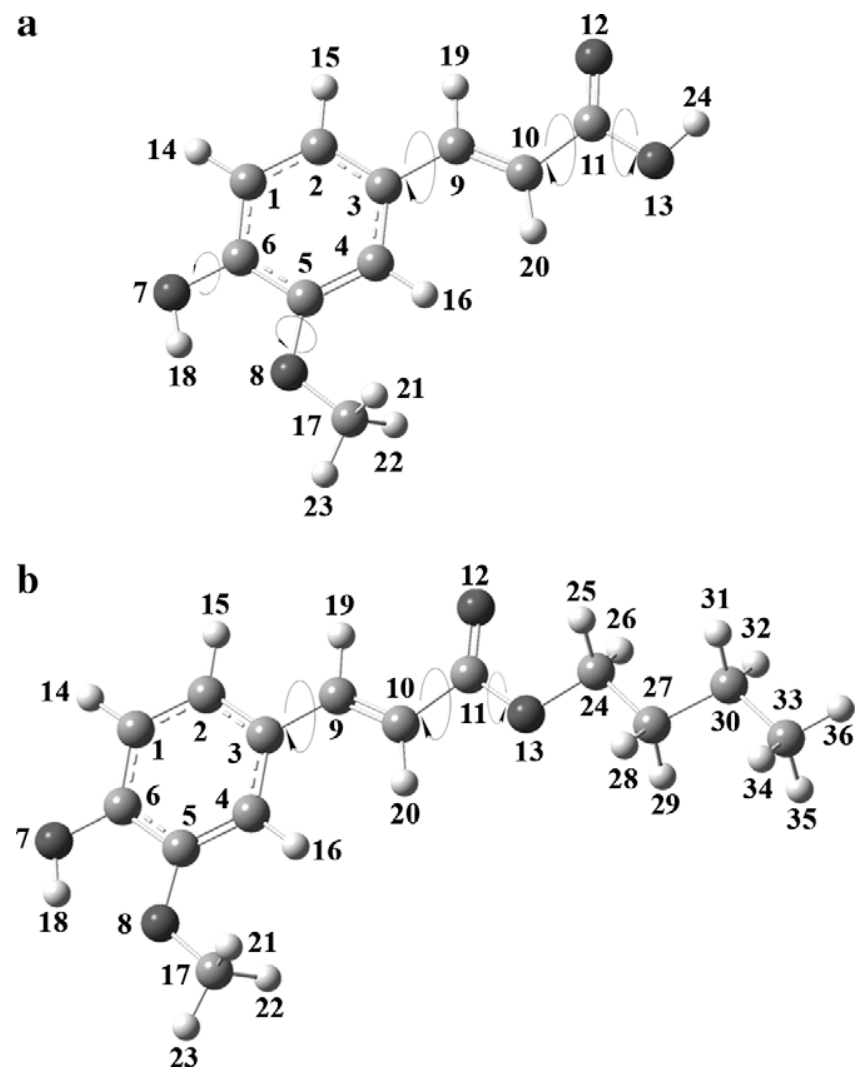

Fig. 1. Schematic representation of the most stable calculated conformers for ferulic acid (a) and butyl ferulate (b). (black: oxygen, gray: carbon, white: hydrogen. The atom numbering is included).
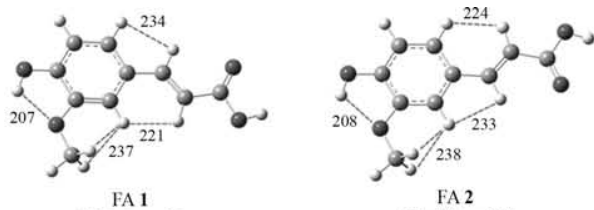

$\Delta E=0.0 ; \mu=4$.

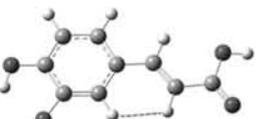

ช

as

FA 3

$\Delta E=3.1 ; \mu=2.6$

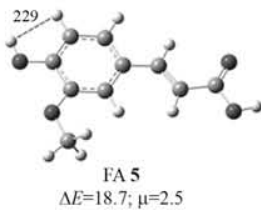

FA 2
$\Delta E=1.0 ; \mu=2.8$

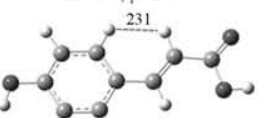

0

as

FA 4
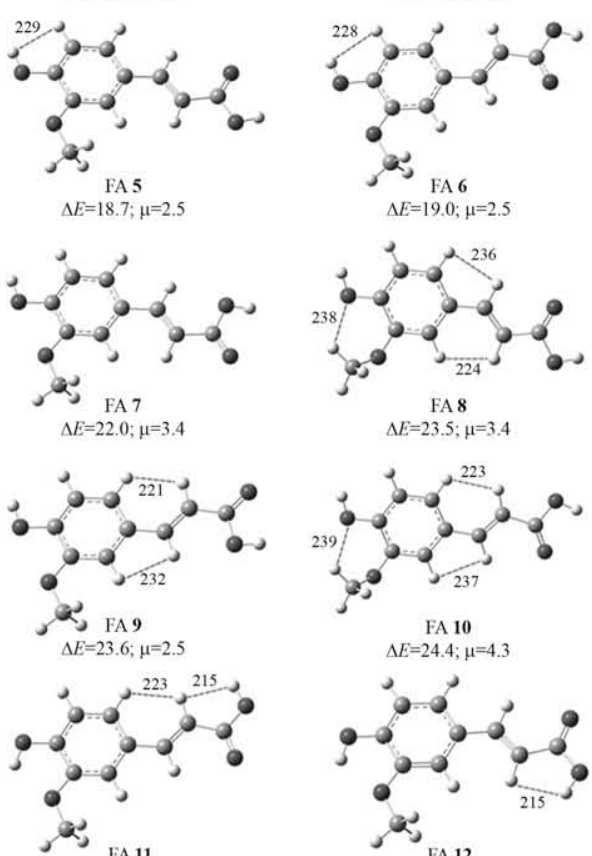

$E=25.4$,<smiles>C1C2C[As]12</smiles>

$\Delta E=25.8 ; \mu=6.8$
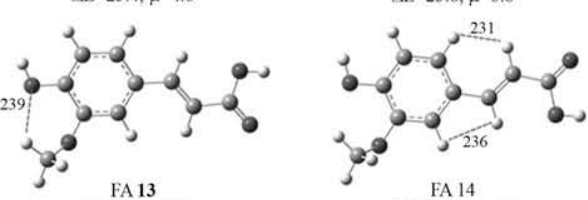

$\underset{\Delta E=7.2 ; \mu=5 \text {. }}{\mathrm{FA} 13}$

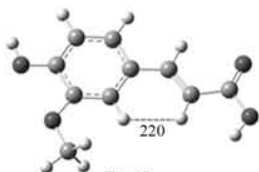

$27.7 ; 1=3$

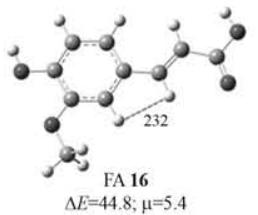

$\Delta E=44.1 ; \mu=5.4$
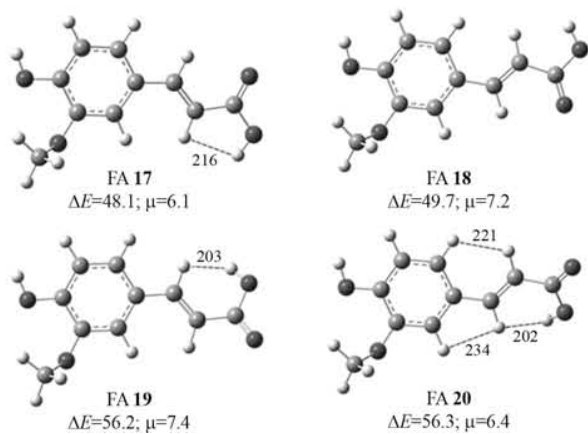

Fig. 2. Representation of the optimised geometries (B3LYP/6-31G(d,p) level of calculation) for $\mathrm{FA}$, displaying the (C) $\mathrm{H} \cdots \mathrm{O},(\mathrm{O}) \mathrm{H} \cdots \mathrm{O},(\mathrm{C}) \mathrm{H} \cdots \mathrm{H}$ and $(\mathrm{O}) \mathrm{H} \cdots \mathrm{H}$ intramolecular interactions. (Relative energies in $\mathrm{kJ} \mathrm{mol}^{-1}$ and total dipole moments $(\mu)$ in Debye. Black: oxygen, gray: carbon, white: hydrogen). 

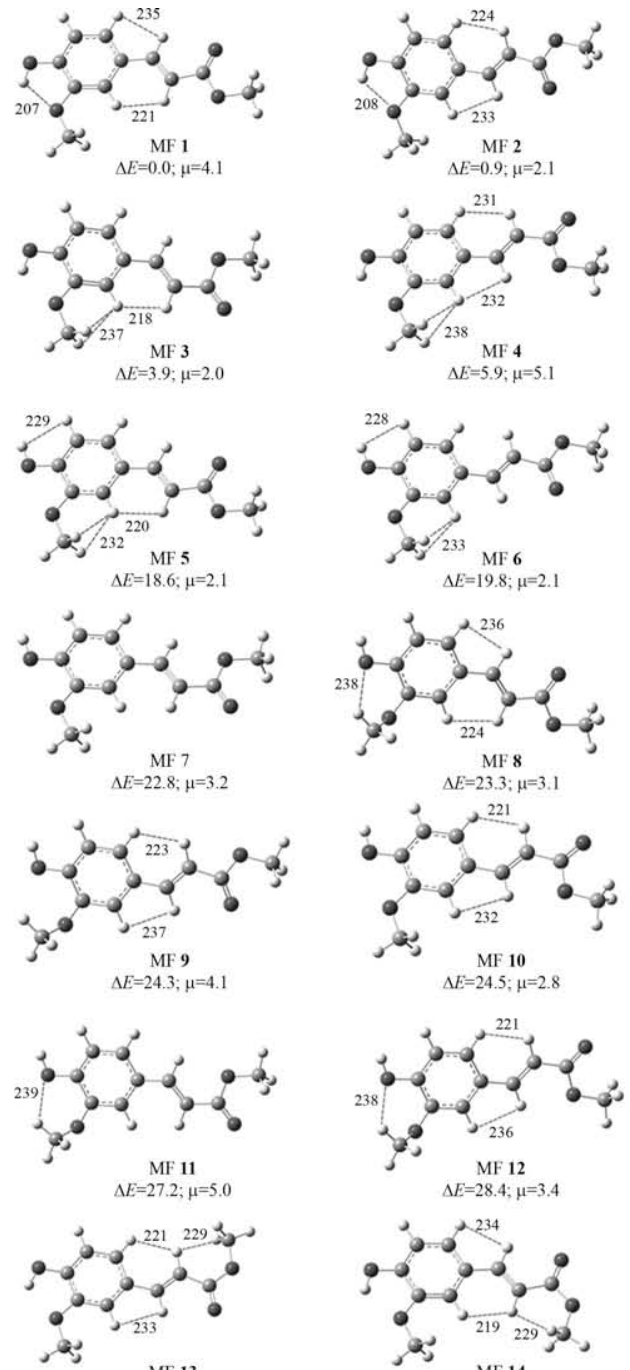

$$
\underset{\Delta E=35.8 ; \mu=3,9}{\operatorname{MF} 13}
$$

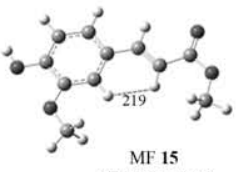
$\Delta E=54.5 ; \mu=5.0$

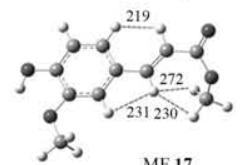$$
\triangle E=55.2 ; \mu=6.6
$$

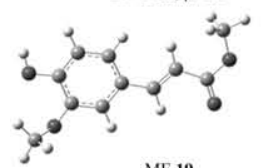

$$
\stackrel{\text { MF } 19}{\Delta E=60.1 ; \mu=7.0}
$$
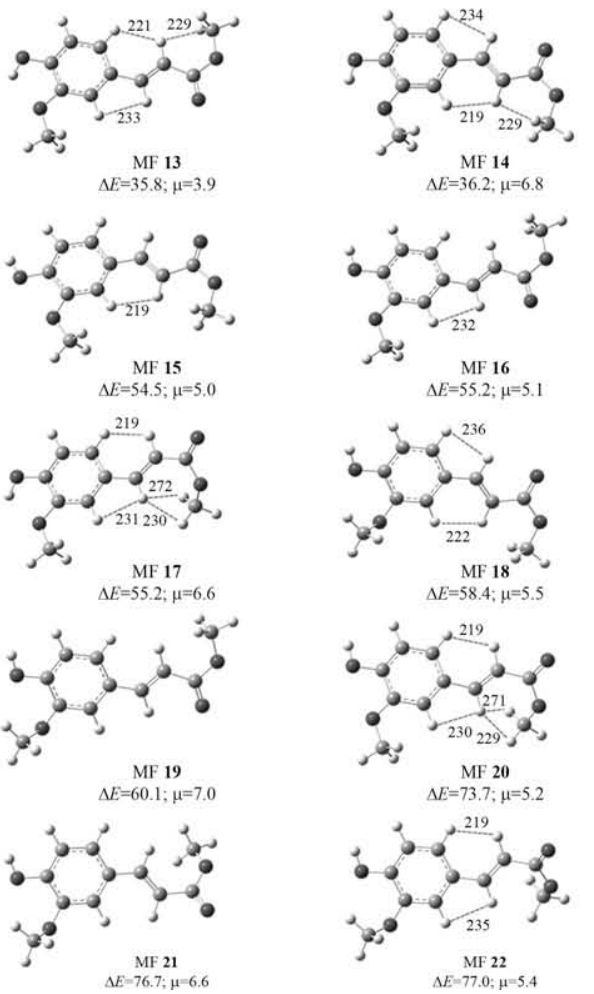

Fig. 3. Representation of the optimised geometries (B3LYP/6-31G(d,p) level of calculation) for MF, displaying the (C) $\mathrm{H} \cdots \mathrm{O},(\mathrm{O}) \mathrm{H} \cdots \mathrm{O},(\mathrm{C}) \mathrm{H} \cdots \mathrm{H}$ and $(\mathrm{O}) \mathrm{H} \cdots \mathrm{H}$ intramolecular interactions. (Relative energies in $\mathrm{kJ} \mathrm{mol}^{-1}$ and total dipole moments $(\mu)$ in Debye. Black: oxygen, gray: carbon, white: hydrogen).
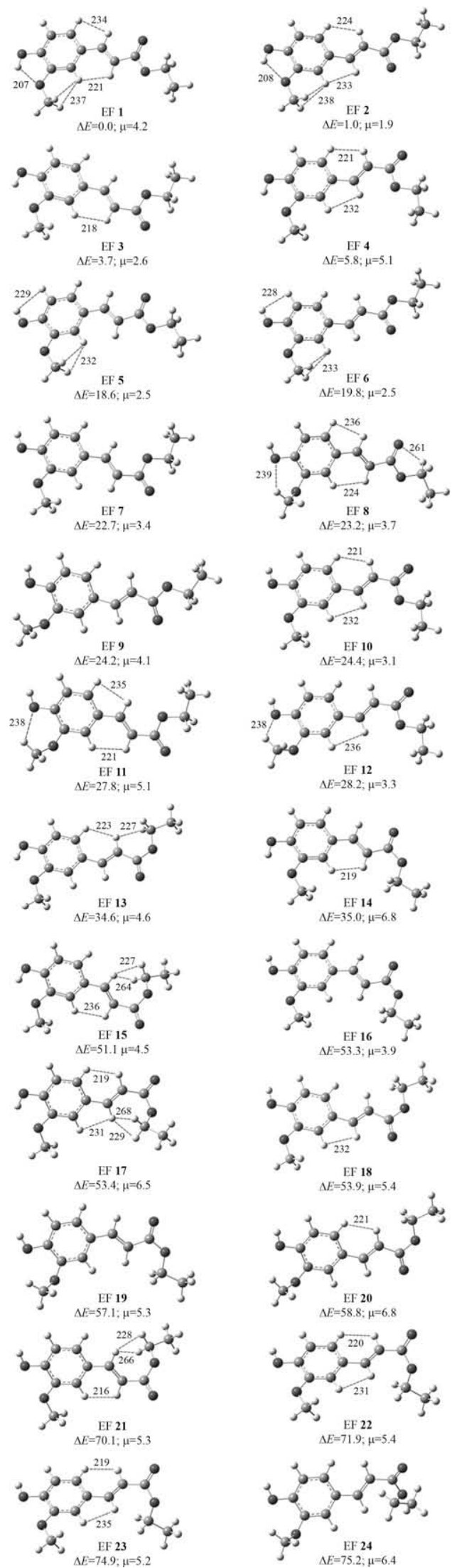

Fig. 4. Representation of the optimised geometries (B3LYP/6-31G(d,p) level of calculation) for EF, displaying the $(\mathrm{C}) \mathrm{H} \cdots \mathrm{O},(\mathrm{O}) \mathrm{H} \cdots \mathrm{O},(\mathrm{C}) \mathrm{H} \cdots \mathrm{H}$ and $(\mathrm{O}) \mathrm{H} \cdots \mathrm{H}$ intramolecular interactions. (Relative energies in $\mathrm{kJ} \mathrm{mol}^{-1}$ and total dipole moments $(\mu)$ in Debye. Black: oxygen, gray: carbon, white: hydrogen). 


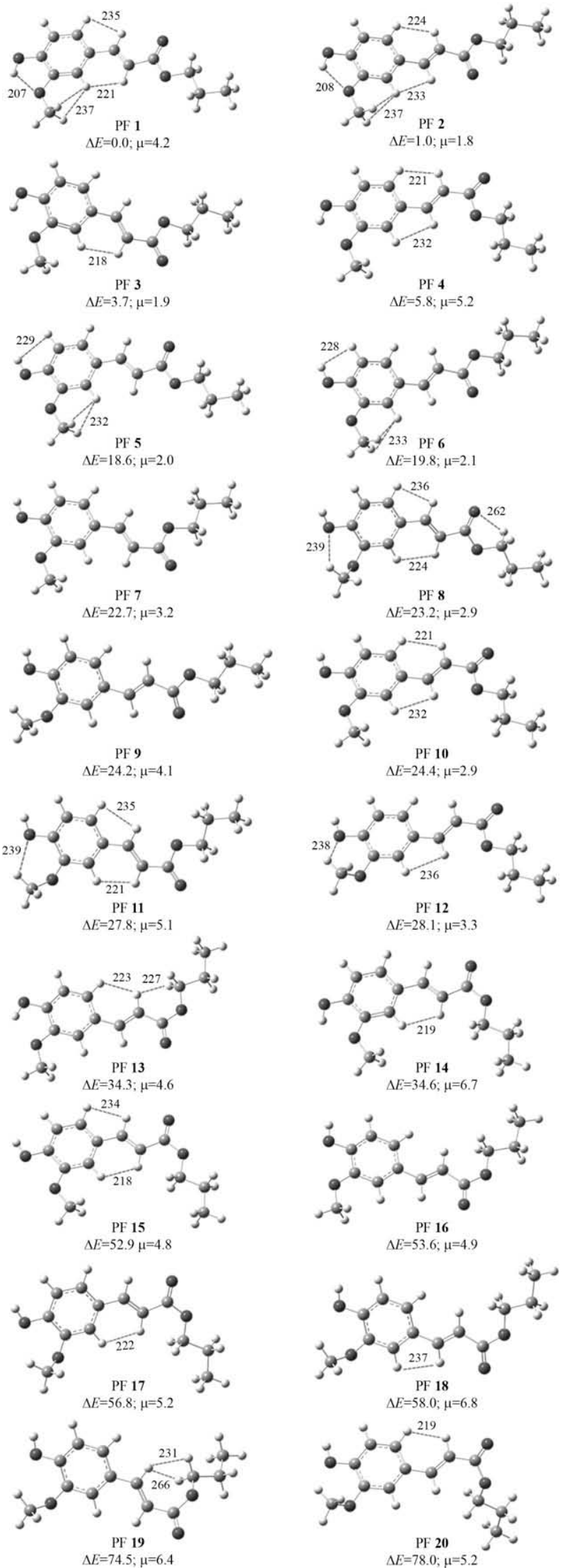

Fig. 5. Representation of the optimised geometries (B3LYP/6-31G(d,p) level of calculation) for $\mathrm{PF}$, displaying (C) $\mathrm{H} \cdots \mathrm{O},(\mathrm{O}) \mathrm{H} \cdots \mathrm{O},(\mathrm{C}) \mathrm{H} \cdots \mathrm{H}$ and $(\mathrm{O}) \mathrm{H} \cdots \mathrm{H}$ intramolecular interactions. (Relative energies in $\mathrm{kJ} \mathrm{mol}^{-1}$ and total dipole moments in Debye. Black: oxygen, gray: carbon, white: hydrogen).
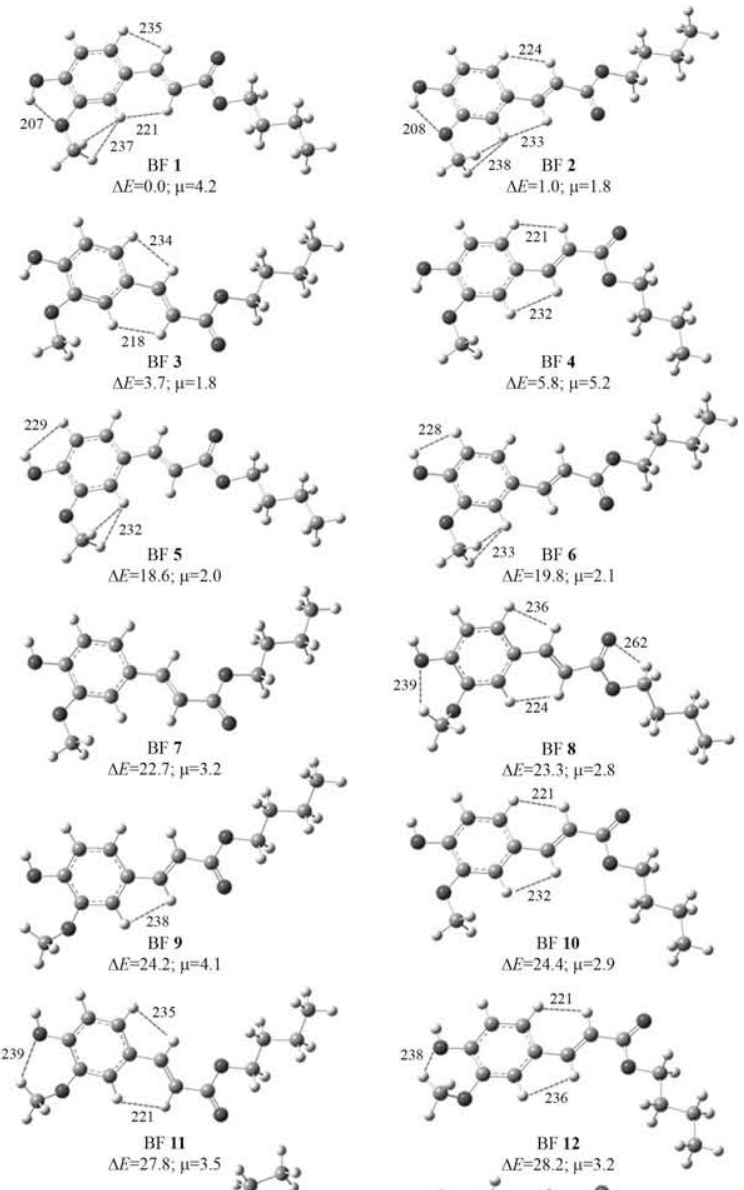

, aj
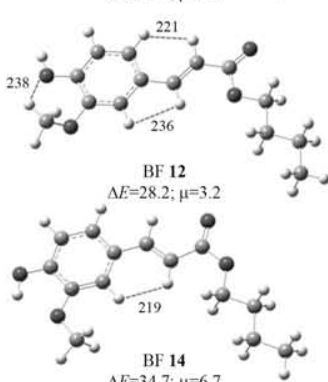

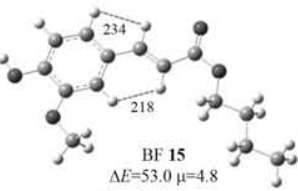

$3 a_{j}^{3}$
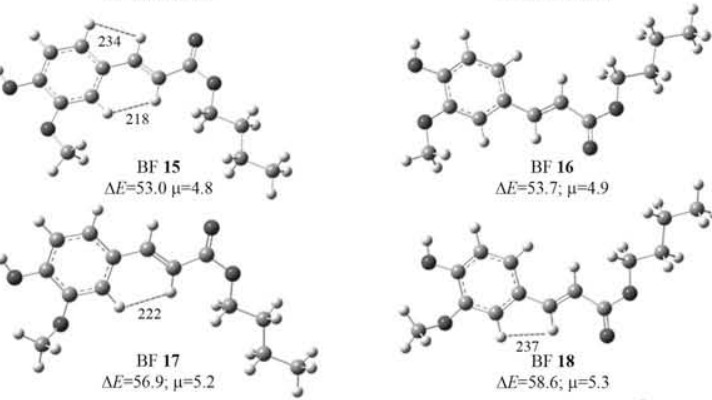

$\sum_{\substack{237 \\ B F \quad 18 \\ \Delta E=58.6 ; \mu=5.3}}$
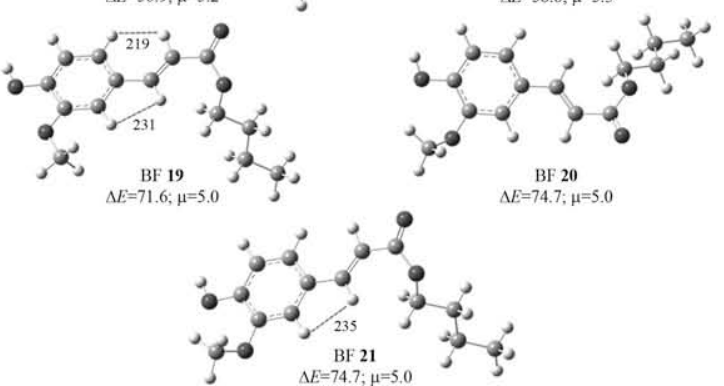

Fig. 6. Representation of the optimised geometries (B3LYP/6-31G(d,p) level of calculation) for $\mathrm{BF}$, displaying the $(\mathrm{C}) \mathrm{H} \cdots \mathrm{O},(\mathrm{O}) \mathrm{H} \cdots \mathrm{O},(\mathrm{C}) \mathrm{H} \cdots \mathrm{H}$ and $(\mathrm{O}) \mathrm{H} \cdots \mathrm{H}$ intramolecular interactions. (Relative energies in $\mathrm{kJ} \mathrm{mol}^{-1}$ and total dipole moments $(\mu)$ in Debye. Black: oxygen, gray: carbon, white: hydrogen). 
The effect of several structural parameters on the overall stability of these molecules was investigated: (i) rotation around the $\left(\mathrm{C}_{3}-\mathrm{C}_{9}\right)$ bond; (ii) syn or anti geometries, defined by a $\left(\mathrm{C}_{9}=\mathrm{C}_{10^{-}}\right.$ $\mathrm{C}_{11}=\mathrm{O}_{12}$ ) dihedral equal to either $0^{\circ}$ or $180^{\circ}$, respectively; (iii) orientation of the $\mathrm{H}_{24}$ atom, in ferulic acid, or of the alkyl ester chain (in the corresponding esters) relative to the carbonyl group, yielding an s-cis or an s-trans conformation; (iv) orientation of the hydroxyl and methoxyl ring substituents, determined by the $\left(\mathrm{C}_{5}-\right.$ $\left.\mathrm{C}_{6}-\mathrm{O}-\mathrm{H}_{18}\right)$ and $\left(\mathrm{C}_{4}-\mathrm{C}_{5}-\mathrm{O}_{8}-\mathrm{C}_{17}\right)$ dihedrals, respectively.

For all the compounds analysed, the most stable structures (conformers 1 to 4, Figs. 2-6) display a quite low energy difference relative to the most stable conformer (between 0.8 and $5.9 \mathrm{~kJ} \mathrm{~mol}^{-1}$ ) (Supplementary material, Figs. S1-S5).

Table 1 comprises the calculated optimised geometrical parameters for all the populated conformers obtained of FA, at $298.15 \mathrm{~K}$, and for an FA 1 dimeric species (FA $\mathbf{1}^{\prime}$ ). These results were compared to the X-ray structural data reported for FA [39], a good agreement having been found. The calculated optimised geometrical parameters for the two most populated conformers of each of the ferulic esters under study are represented in Table 2. Geomet-

Table 1

Experimental and calculated (B3LYP/6-31G(d,p)) optimised geometries for the most stable conformers of FA (1-4) and for a dimeric specie of FA 1 (FA $\mathbf{1}^{\prime}$ ).

\begin{tabular}{|c|c|c|c|c|c|c|}
\hline Parameters $^{\mathrm{a}}$ & Exp. $^{b}$ & $\begin{array}{l}\text { FA } 1 \\
48 \%\end{array}$ & FA $\mathbf{1}^{\prime}$ & $\begin{array}{l}\text { FA 2 } \\
32 \%\end{array}$ & $\begin{array}{l}\text { FA } 3 \\
14 \%\end{array}$ & $\begin{array}{l}\text { FA } 4 \\
6 \%\end{array}$ \\
\hline \multicolumn{7}{|l|}{ Bond lengths (pm) } \\
\hline $\mathrm{C}_{6}-\mathrm{O}_{7}$ & 136.3 & 135.5 & 135.5 & 135.6 & 135.5 & 135.6 \\
\hline $\mathrm{C}_{5}-\mathrm{O}_{8}$ & 136.9 & 137.3 & 137.3 & 137.3 & 137.3 & 137.4 \\
\hline $\mathrm{O}_{8}-\mathrm{C}_{17}$ & 142.0 & 142.1 & 142.2 & 142.1 & 142.1 & 142.1 \\
\hline $\mathrm{C}_{11}-\mathrm{O}_{12}$ & 125.7 & 121.1 & 124.0 & 121.8 & 121.8 & 121.7 \\
\hline $\mathrm{C}_{11}-\mathrm{O}_{13}$ & 128.9 & 136.2 & 132.4 & 136.1 & 136.3 & 136.4 \\
\hline $\mathrm{C}_{1}-\mathrm{C}_{2}$ & 135.8 & 139.4 & 139.4 & 139.1 & 139.4 & 139.1 \\
\hline$C_{2}-C_{3}$ & 139.8 & 140.3 & 140.3 & 140.5 & 140.3 & 140.5 \\
\hline$C_{3}-C_{4}$ & 139.8 & 141.5 & 141.5 & 141.2 & 141.5 & 141.3 \\
\hline $\mathrm{C}_{4}-\mathrm{C}_{5}$ & 137.1 & 138.3 & 138.3 & 138.7 & 138.4 & 138.7 \\
\hline $\mathrm{C}_{5}-\mathrm{C}_{6}$ & 139.4 & 141.1 & 141.1 & 141.1 & 141.6 & 141.1 \\
\hline$C_{1}-C_{6}$ & 137.7 & 139.0 & 139.0 & 139.4 & 139.0 & 139.4 \\
\hline $\mathrm{C}_{3}-\mathrm{C}_{9}$ & 145.4 & 145.6 & 145.6 & 145.7 & 145.8 & 145.9 \\
\hline $\mathrm{C}_{9}-\mathrm{C}_{10}$ & 132.9 & 134.8 & 134.8 & 134.8 & 134.9 & 134.9 \\
\hline$C_{10}-C_{11}$ & 145.8 & 147.0 & 147.0 & 147.0 & 146.8 & 146.8 \\
\hline \multicolumn{7}{|l|}{ Bond angles $\left({ }^{\circ}\right)$} \\
\hline $\mathrm{O}_{12}-\mathrm{C}_{11}-\mathrm{O}_{13}$ & 122.2 & 121.9 & 124.8 & 121.9 & 121.6 & 121.6 \\
\hline $\mathrm{C}_{1}-\mathrm{C}_{6}-\mathrm{O}_{7}$ & 119.2 & 120.5 & 120.5 & 120.2 & 120.5 & 120.2 \\
\hline $\mathrm{C}_{4}-\mathrm{C}_{5}-\mathrm{O}_{8}$ & 126.1 & 126.3 & 126.3 & 126.3 & 126.3 & 126.3 \\
\hline $\mathrm{C}_{10}-\mathrm{C}_{11}-\mathrm{O}_{12}$ & 117.3 & 126.6 & 122.2 & 126.5 & 124.3 & 124.3 \\
\hline $\mathrm{C}_{10}-\mathrm{C}_{11}-\mathrm{O}_{13}$ & 120.4 & 111.5 & 113.4 & 111.5 & 114.1 & 114.1 \\
\hline$C_{1}-C_{2}-C_{3}$ & 121.3 & 121.4 & 121.4 & 121.0 & 121.4 & 121.0 \\
\hline$C_{2}-C_{3}-C_{4}$ & 118.0 & 118.4 & 118.4 & 118.4 & 118.4 & 118.4 \\
\hline$C_{3}-C_{4}-C_{5}$ & 120.9 & 120.5 & 120.2 & 120.6 & 120.5 & 120.7 \\
\hline$C_{2}-C_{1}-C_{6}$ & 119.7 & 119.8 & 119.8 & 120.2 & 119.8 & 120.2 \\
\hline $\mathrm{C}_{4}-\mathrm{C}_{3}-\mathrm{C}_{9}$ & 122.6 & 122.7 & 122.7 & 118.2 & 122.7 & 118.2 \\
\hline$C_{3}-C_{9}-C_{10}$ & 128.9 & 128.2 & 128.1 & 128.2 & 127.7 & 127.6 \\
\hline$C_{9}-C_{10}-C_{11}$ & 121.2 & 120.0 & 120.7 & 119.8 & 124.0 & 123.8 \\
\hline $\mathrm{C}_{5}-\mathrm{O}_{8}-\mathrm{C}_{17}$ & 117.4 & 118.3 & 118.3 & 118.2 & 118.3 & 118.2 \\
\hline \multicolumn{7}{|l|}{ Dihedral angles $\left({ }^{\circ}\right)$} \\
\hline$C_{4}-C_{5}-C_{6}-O_{7}$ & 179.1 & 180.0 & 180.0 & 180.0 & 180.0 & 180.0 \\
\hline $\mathrm{C}_{3}-\mathrm{C}_{4}-\mathrm{C}_{5}-\mathrm{O}_{8}$ & - & 180.0 & 180.0 & 180.0 & 180.0 & 180.0 \\
\hline $\mathrm{C}_{9}-\mathrm{C}_{10}-\mathrm{C}_{11}-\mathrm{O}_{12}$ & 3.2 & 0.0 & 0.0 & 0.0 & 180.0 & 180.0 \\
\hline $\mathrm{C}_{9}-\mathrm{C}_{10}-\mathrm{C}_{11}-\mathrm{O}_{13}$ & -176.9 & 180.0 & 180.0 & 180.0 & 0.0 & 0.0 \\
\hline $\mathrm{C}_{4}-\mathrm{C}_{5}-\mathrm{O}_{8}-\mathrm{C}_{17}$ & 0.4 & 0.0 & 0.0 & 0.0 & 0.0 & 0.0 \\
\hline$C_{1}-C_{2}-C_{3}-C_{4}$ & - & 0.0 & 0.0 & 0.0 & 0.0 & 0.0 \\
\hline$C_{5}-C_{4}-C_{3}-C_{2}$ & - & 0.0 & 0.0 & 0.0 & 0.0 & 0.0 \\
\hline$C_{3}-C_{2}-C_{1}-C_{6}$ & - & 0.0 & 0.0 & 0.0 & 0.0 & 0.0 \\
\hline$C_{5}-C_{4}-C_{3}-C_{9}$ & - & 180.0 & 180.0 & 180.0 & 180.0 & 180.0 \\
\hline$C_{2}-C_{3}-C_{9}-C_{10}$ & -178.2 & 180.0 & 180.0 & 0.0 & 180.0 & 0.0 \\
\hline$C_{3}-C_{9}-C_{10}-C_{11}$ & - & 180.0 & 180.0 & 180.0 & 180.0 & 180.0 \\
\hline $\mathrm{O}_{12}-\mathrm{C}_{11}-\mathrm{O}_{13}-\mathrm{H}_{24}$ & - & 0.0 & 0.0 & 0.0 & 0.0 & 0.0 \\
\hline
\end{tabular}

\footnotetext{
a Atoms are numbered according to Fig. 1.

b Data obtained from X-ray diffractometry [39].

c Boltzmann populations at $298.15 \mathrm{~K}$.
}

rical parameters involving the hydrogen atoms for FA and ferulates are available in the Supplementary material, Tables S1 and S2, respectively).

\subsection{Rotational isomerism}

For the lowest energy conformers (s-cis), the potential-energy profiles for the internal rotation around the $\left(C_{3}-C_{9}\right)$ and $\left(C_{10}-C_{11}\right)$ bonds were determined and analysed, for both FA and the ferulates, and the corresponding rotational energy barriers were calculated (at the B3LYP/6-31(d,p) level). For these internal rotations, the conformational behaviour and the respective Fourier deconvolutions for FA are showed in Figs. 7 and 8, respectively. These results may be extended to all the ferulates presently investigated, since similar rotational profiles were obtained for these systems and the parent acid. Similarly, the potential-energy plots for the rotation around $\left(\mathrm{C}_{6}-\mathrm{O}_{7}\right)$ and $\left(\mathrm{C}_{5}-\mathrm{O}_{8}\right)$ were calculated only for the most stable FA conformer (Figs. 9 and 10, respectively. Furthermore, the potential-energy profile around $\left(\mathrm{C}_{11}-\mathrm{O}_{13}\right)$ for both the acid and the esters ( $\mathrm{s}$-cis to s-trans conversion) were obtained. The corresponding conformational behaviour and its Fourier deconvolutions are represented in Figs. 11 and 12 for FA and MF, respectively, the latter being similar to the results obtained for $\mathrm{EF}, \mathrm{PF}$ and $\mathrm{BF}$.

Table 3 summarises the calculated energy differences for FA and the ferulates presently studied, as well as the energy barriers and Fourier components $\left(V_{n}\right)$ calculated for the internal rotations around the $\left(\mathrm{C}_{3}-\mathrm{C}_{9}\right),\left(\mathrm{C}_{11}-\mathrm{C}_{10}\right)$ and $\left(\mathrm{O}_{11}-\mathrm{O}_{13}\right)$ bonds.

\section{Discussion}

The conformational results presently obtained for the systems under study will be discussed in the light of the main parameters that determine their overall structure and stability: steric repulsions; inductive and resonance effects; and intramolecular hydrogen bond interactions. In addition to these, other factors also account for the conformational behaviour of this kind of hydroxycinnamic derivatives, namely electrostatic interactions, or intermolecular hydrogen close contacts $(\mathrm{C}) \mathrm{H} \cdots \mathrm{O}$ and $(\mathrm{O}) \mathrm{H} \cdots \mathrm{O}$ (e.g. yielding dimeric species).

\subsection{Conformational preferences of ferulic acid and its ester derivatives}

A typical structural parameter of cinnamic acids and their derivatives is the partial double bond character of the $\left(C_{3}-C_{9}\right)$ and $\left(C_{10^{-}}\right.$ $C_{11}$ ) bonds ( $d=145-147 \mathrm{pm}$, Tables 1 and 2$)$, reflecting an effective $\pi$-electron delocalisation between the aromatic ring, the unsaturated pendant chain and the carboxylic moiety. The $\left(C_{4}-C_{5}-O_{8}\right)$ bond angle was found to widen, in order to minimise the steric interactions between $\mathrm{H}_{16}$ and the $\mathrm{H}_{21}$ and $\mathrm{H}_{22}$ atoms bonded to $\mathrm{C}_{17}\left(d=237 \mathrm{pm} ; \alpha\left(\mathrm{C}_{4}-\mathrm{C}_{5}-\mathrm{O}_{8}\right)=126^{\circ}\right)$. Moreover, the opening of the $\left(C_{3}-C_{9}-C_{10}\right)$ angle $\left(\alpha=128^{\circ}\right)$, as well as the difference found for the $\left(C_{4}-C_{3}-C_{9}\right)$ angle between the conformers displaying a $\left(C_{2}-C_{3}-C_{9}-C_{10}\right)$ dihedral of either $180^{\circ}$ and $0^{\circ}$, are mainly due to the steric hindrance between $\mathrm{H}_{20}$ and $\mathrm{H}_{16}\left(d=221 \mathrm{pm}, \alpha\left(\mathrm{C}_{4}-\mathrm{C}_{3}-\right.\right.$ $\left.\mathrm{C}_{9}\right)=123^{\circ}$; e.g. conformer $\mathbf{1}$ ), or between $\mathrm{H}_{20}$ and $\mathrm{H}_{15}$ $\left(d=224 \mathrm{pm}, \alpha\left(C_{4}-C_{3}-C_{9}\right)=118^{\circ} ;\right.$ e.g. conformer 2) (Figs. 2-6, Tables 1 and 2).

As expected, the calculated bond lengths and bond angles involving the carboxylic group in FA (gas-phase) differ from its reported crystal parameters: $d\left(C_{11}-\mathrm{O}_{12}\right)=121$ vs. $126 \mathrm{pm} ; d\left(\mathrm{C}_{11}\right.$ $\left.\mathrm{O}_{13}\right)=136$ vs. $129 \mathrm{pm} ; \alpha\left(\mathrm{C}_{10}-\mathrm{C}_{11}-\mathrm{O}_{12}\right)=127^{\circ}$ vs. $117^{\circ} ; \alpha\left(\mathrm{C}_{10}-\mathrm{C}_{11^{-}}\right.$ $\left.\mathrm{O}_{13}\right)=111^{\circ} v s .120^{\circ}$, respectively (Table 1 ). In fact, when comparing the structures calculated for FA $\mathbf{1}$ and the corresponding dimer FA $\mathbf{1}^{\prime}$ (which is similar to the reported FA crystal structure), an in- 
Table 2

Calculated (B3LYP/6-31G(d,p)) optimised geometries for the most stable conformers of MF, EF, PF and BF.

\begin{tabular}{|c|c|c|c|c|c|c|c|c|}
\hline Parameter $^{\mathrm{a}}$ & $\begin{array}{l}\text { MF 1 } \\
51 \%^{b}\end{array}$ & $\begin{array}{l}\text { MF } 2 \\
34 \%\end{array}$ & $\begin{array}{l}\text { EF 1 } \\
49 \%\end{array}$ & $\begin{array}{l}\text { EF } 2 \\
35 \%\end{array}$ & $\begin{array}{l}\text { PF } 1 \\
49 \%\end{array}$ & $\begin{array}{l}\text { PF } 2 \\
35 \%\end{array}$ & $\begin{array}{l}\text { BF } 1 \\
49 \%\end{array}$ & $\begin{array}{l}\text { BF } 2 \\
35 \%\end{array}$ \\
\hline \multicolumn{9}{|l|}{ Bond lengths (pm) } \\
\hline $\mathrm{C}_{6}-\mathrm{O}_{7}$ & 135.6 & 135.7 & 135.6 & 135.7 & 135.6 & 135.7 & 135.6 & 135.7 \\
\hline $\mathrm{C}_{5}-\mathrm{O}_{8}$ & 137.3 & 137.4 & 137.3 & 137.4 & 137.3 & 137.4 & 137.3 & 137.4 \\
\hline $\mathrm{O}_{8}-\mathrm{C}_{17}$ & 142.1 & 142.1 & 142.1 & 142.1 & 142.1 & 142.1 & 142.2 & 142.1 \\
\hline $\mathrm{C}_{11}-\mathrm{O}_{12}$ & 121.8 & 121.8 & 121.8 & 121.9 & 121.8 & 121.9 & 121.8 & 121.9 \\
\hline $\mathrm{C}_{11}-\mathrm{O}_{13}$ & 136.0 & 136.0 & 136.0 & 135.8 & 135.9 & 135.8 & 135.9 & 135.8 \\
\hline $\mathrm{O}_{13}-\mathrm{C}_{24}$ & 143.3 & 143.3 & 143.3 & 144.2 & 144.1 & 144.1 & 144.2 & 144.2 \\
\hline $\mathrm{C}_{1}-\mathrm{C}_{2}$ & 139.4 & 139.1 & 139.4 & 139.1 & 139.4 & 139.1 & 139.4 & 139.1 \\
\hline $\mathrm{C}_{2}-\mathrm{C}_{3}$ & 140.3 & 140.5 & 140.3 & 140.5 & 140.3 & 140.5 & 140.3 & 140.5 \\
\hline $\mathrm{C}_{3}-\mathrm{C}_{4}$ & 141.5 & 141.3 & 141.5 & 141.3 & 141.5 & 141.3 & 141.5 & 141.3 \\
\hline$C_{4}-C_{5}$ & 138.4 & 138.7 & 138.4 & 138.7 & 138.4 & 138.7 & 138.4 & 138.7 \\
\hline$C_{5}-C_{6}$ & 141.5 & 141.1 & 141.5 & 141.1 & 141.5 & 141.1 & 141.5 & 141.1 \\
\hline$C_{1}-C_{6}$ & 139.0 & 139.4 & 139.0 & 139.4 & 139.0 & 139.4 & 139.0 & 139.4 \\
\hline $\mathrm{C}_{3}-\mathrm{C}_{9}$ & 145.7 & 145.8 & 145.7 & 145.8 & 145.7 & 145.8 & 145.7 & 145.8 \\
\hline$C_{9}-C_{10}$ & 134.8 & 134.7 & 134.8 & 134.7 & 134.7 & 134.7 & 134.7 & 134.7 \\
\hline$C_{10}-C_{11}$ & 147.2 & 147.3 & 147.3 & 147.3 & 147.3 & 147.4 & 147.3 & 147.4 \\
\hline $\mathrm{C}_{24}-\mathrm{C}_{27}$ & - & - & 151.7 & 151.7 & 152.1 & 152.1 & 152.0 & 152.0 \\
\hline$C_{27}-C_{30}$ & - & - & - & - & 153.2 & 153.2 & 153.4 & 153.4 \\
\hline$C_{30}-C_{33}$ & - & - & - & - & - & - & 153.1 & 153.1 \\
\hline \multicolumn{9}{|l|}{ Bond angles $\left({ }^{\circ}\right)$} \\
\hline $\mathrm{O}_{12}-\mathrm{C}_{11}-\mathrm{O}_{13}$ & 122.9 & 122.9 & 123.1 & 123.1 & 123.1 & 123.1 & 123.1 & 123.1 \\
\hline $\mathrm{C}_{1}-\mathrm{C}_{6}-\mathrm{O}_{7}$ & 120.5 & 120.2 & 120.5 & 120.3 & 120.5 & 120.3 & 120.5 & 120.3 \\
\hline $\mathrm{C}_{4}-\mathrm{C}_{5}-\mathrm{O}_{8}$ & 126.3 & 126.3 & 126.3 & 126.3 & 126.3 & 126.3 & 126.3 & 126.3 \\
\hline $\mathrm{C}_{10}-\mathrm{C}_{11}-\mathrm{O}_{12}$ & 126.4 & 126.4 & 126.2 & 126.1 & 126.2 & 126.1 & 126.1 & 126.1 \\
\hline $\mathrm{C}_{10}-\mathrm{C}_{11}-\mathrm{O}_{13}$ & 110.7 & 110.7 & 110.7 & 110.7 & 110.7 & 110.7 & 110.7 & 110.7 \\
\hline $\mathrm{C}_{11}-\mathrm{O}_{13}-\mathrm{C}_{24}$ & 115.0 & 115.0 & 115.6 & 115.6 & 115.6 & 115.7 & 115.6 & 115.7 \\
\hline $\mathrm{O}_{13}-\mathrm{C}_{24}-\mathrm{C}_{27}$ & - & - & 107.5 & 107.5 & 107.8 & 107.8 & 107.8 & 107.8 \\
\hline$C_{1}-C_{2}-C_{3}$ & 121.4 & 121.1 & 121.4 & 121.1 & 121.4 & 121.1 & 121.4 & 121.1 \\
\hline$C_{2}-C_{3}-C_{4}$ & 118.4 & 118.4 & 118.4 & 118.4 & 118.4 & 118.4 & 118.4 & 118.4 \\
\hline$C_{3}-C_{4}-C_{5}$ & 120.3 & 120.7 & 120.3 & 120.7 & 120.3 & 120.7 & 120.3 & 120.7 \\
\hline$C_{2}-C_{1}-C_{6}$ & 119.8 & 120.2 & 119.8 & 120.2 & 119.8 & 120.2 & 119.8 & 120.2 \\
\hline$C_{4}-C_{3}-C_{9}$ & 122.7 & 118.2 & 122.7 & 118.2 & 122.7 & 118.2 & 122.7 & 118.2 \\
\hline$C_{3}-C_{9}-C_{10}$ & 128.2 & 128.2 & 128.2 & 128.2 & 128.2 & 128.2 & 128.2 & 128.2 \\
\hline$C_{9}-C_{10}-C_{11}$ & 120.1 & 119.9 & 120.1 & 119.9 & 120.1 & 119.9 & 120.1 & 119.9 \\
\hline$C_{24}-C_{27}-C_{30}$ & - & - & - & - & 111.9 & 111.9 & 112.3 & 112.3 \\
\hline$C_{27}-C_{30}-C_{33}$ & - & - & - & - & - & - & 112.9 & 112.9 \\
\hline $\mathrm{C}_{5}-\mathrm{O}_{8}-\mathrm{C}_{17}$ & 118.2 & 118.2 & 118.3 & 118.2 & 118.3 & 118.2 & 118.3 & 118.2 \\
\hline \multicolumn{9}{|l|}{ Dihedral angle $\left(^{\circ}\right)$} \\
\hline $\mathrm{C}_{4}-\mathrm{C}_{5}-\mathrm{C}_{6}-\mathrm{O}_{7}$ & 180.0 & 180.0 & 180.0 & 180.0 & 180.0 & 180.0 & 180.0 & 180.0 \\
\hline $\mathrm{C}_{3}-\mathrm{C}_{4}-\mathrm{C}_{5}-\mathrm{O}_{8}$ & 180.0 & 180.0 & 180.0 & 180.0 & 180.0 & 180.0 & 180.0 & 180.0 \\
\hline $\mathrm{C}_{9}-\mathrm{C}_{10}-\mathrm{C}_{11}-\mathrm{O}_{12}$ & 0.0 & 0.0 & 0.0 & 0.0 & 0.0 & 0.0 & 0.0 & 0.0 \\
\hline $\mathrm{C}_{9}-\mathrm{C}_{10}-\mathrm{C}_{11}-\mathrm{O}_{13}$ & 180.0 & 180.0 & 180.0 & 180.0 & 180.0 & 180.0 & 180.0 & 180.0 \\
\hline $\mathrm{C}_{4}-\mathrm{C}_{5}-\mathrm{O}_{8}-\mathrm{C}_{17}$ & 0.0 & 0.0 & 0.0 & 0.0 & 0.0 & 0.0 & 0.0 & 0.0 \\
\hline $\mathrm{O}_{12}-\mathrm{C}_{11}-\mathrm{O}_{13}-\mathrm{C}_{24}$ & 180.0 & 180.0 & 180.0 & 180.0 & 180.0 & 180.0 & 180.0 & 180.0 \\
\hline $\mathrm{C}_{11}-\mathrm{O}_{13}-\mathrm{C}_{24}-\mathrm{C}_{27}$ & - & - & 180.0 & 180.0 & 180.0 & 180.0 & 180.0 & 180.0 \\
\hline $\mathrm{O}_{13}-\mathrm{C}_{24}-\mathrm{C}_{27}-\mathrm{C}_{30}$ & - & - & - & - & 180.0 & 180.0 & 180.0 & 180.0 \\
\hline$C_{1}-C_{2}-C_{3}-C_{4}$ & 0.0 & 0.0 & 0.0 & 0.0 & 0.0 & 0.0 & 0.0 & 0.0 \\
\hline$C_{2}-C_{3}-C_{4}-C_{5}$ & 0.0 & 0.0 & 0.0 & 0.0 & 0.0 & 0.0 & 0.0 & 0.0 \\
\hline$C_{6}-C_{1}-C_{2}-C_{3}$ & 0.0 & 0.0 & 0.0 & 0.0 & 0.0 & 0.0 & 0.0 & 0.0 \\
\hline$C_{5}-C_{4}-C_{3}-C_{9}$ & 180.0 & 180.0 & 180.0 & 180.0 & 180.0 & 180.0 & 180.0 & 180.0 \\
\hline$C_{2}-C_{3}-C_{9}-C_{10}$ & 180.0 & 0.0 & 180.0 & 0.0 & 180.0 & 0.0 & 180.0 & 0.0 \\
\hline$C_{3}-C_{9}-C_{10}-C_{11}$ & 180.0 & 180.0 & 180.0 & 180.0 & 180.0 & 180.0 & 180.0 & 180.0 \\
\hline$C_{24}-C_{27}-C_{30}-C_{33}$ & - & - & - & - & - & - & 180.0 & 180.0 \\
\hline
\end{tabular}

a Atoms are numbered according to Fig. 1.

b Boltzmann populations of the most stable conformers at $298.15 \mathrm{~K}$.

crease in the $\left(\mathrm{C}_{11}-\mathrm{O}_{12}\right)$ bond length $(d=124 \mathrm{pm})$ coupled to a decrease in $\left(\mathrm{C}_{11}-\mathrm{O}_{13}\right)(d=132 \mathrm{pm})$ are observed. Also, the angles $\left(\mathrm{C}_{10}-\mathrm{C}_{11}-\mathrm{O}_{12}\right)$ and $\left(\mathrm{C}_{10}-\mathrm{C}_{11}-\mathrm{O}_{13}\right)$ tend for quite smaller in the dimeric species ( $\alpha=122^{\circ} ; \alpha=113^{\circ}$, respectively) (Table 1 ), due to the formation of intermolecular H-type interactions. Actually, the crystallographic results rely on a model that considers the formation of centrosymmetric dimers for carboxylic acids in the condensed phase, where an eight-membered intermolecular ring is formed through two $(\mathrm{O}) \mathrm{H} \cdots \mathrm{O}(=\mathrm{C})$ hydrogen bonds [40-42]. For this dimeric unit two possible tautomers coexist, interconvertible through a symmetric transition state. This explains the similarity between the crystallographic results and the calculated bond lengths $\left(\mathrm{C}_{11}-\mathrm{O}_{12}\right)$ and $\left(\mathrm{C}_{11}-\mathrm{O}_{13}\right)$, and bond angles $\left(\mathrm{C}_{10}-\mathrm{C}_{11}-\mathrm{O}_{12}\right)$ and $\left(\mathrm{C}_{10}-\mathrm{C}_{11}-\mathrm{O}_{13}\right)$ for the dimer FA $\mathbf{1}^{\prime}$, as well as the difference between these and the corresponding parameters obtained for the monomer FA 1 (Table 1).

The planar conformers 1-4 display $\left(\mathrm{C}_{5}-\mathrm{C}_{6}-\mathrm{O}_{7}-\mathrm{H}_{18}\right)$ and $\left(\mathrm{C}_{4}-\mathrm{C}_{5}-\right.$ $\mathrm{O}_{8}-\mathrm{C}_{17}$ ) dihedral angles equal to $0^{\circ}$, coupled to an s-cis conformation defined by the $\left(\mathrm{O}_{12}-\mathrm{C}_{11}-\mathrm{O}_{13}-\mathrm{H}_{24}\right)$ or $\left(\mathrm{O}_{12}-\mathrm{C}_{11}-\mathrm{O}_{13}-\mathrm{C}_{24}\right)$ dihedrals (FA or the corresponding esters, respectively) (Figs. 2-6, Tables 1 and 2). The most favourable combination of these dihedrals, that characterise the preferential orientation of the hydroxyl and methoxyl groups relative to the aromatic ring, allow a highly stabilising, medium strength intramolecular hydrogen bond to be formed $\left(d(\mathrm{O}) \mathrm{H} \cdots \mathrm{O}\left(\mathrm{CH}_{3}\right)=207-208 \mathrm{pm}\right)$ (Figs. 2-6). Moreover, the $\mathrm{s}$-cis conformers are highly favoured, since they enable the minimi- 


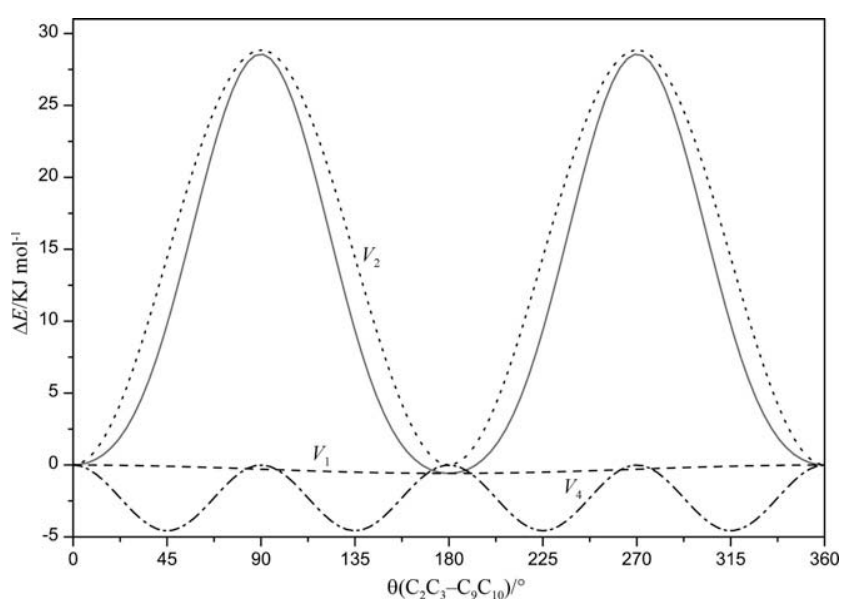

Fig. 7. Optimised conformational energy profiles (B3LYP/6-31G(d,p)) for the internal rotation around the $\left(\mathrm{C}_{3}-\mathrm{C}_{9}\right)$ bond within $\mathrm{FA}$, and its Fourier deconvolutions $\left(V_{1}=-0.6 \mathrm{~kJ} \mathrm{~mol}^{-1}, V_{2}=28.8 \mathrm{~kJ} \mathrm{~mol}^{-1}, V_{4}=-4.6 \mathrm{~kJ} \mathrm{~mol}^{-1}\right)$.

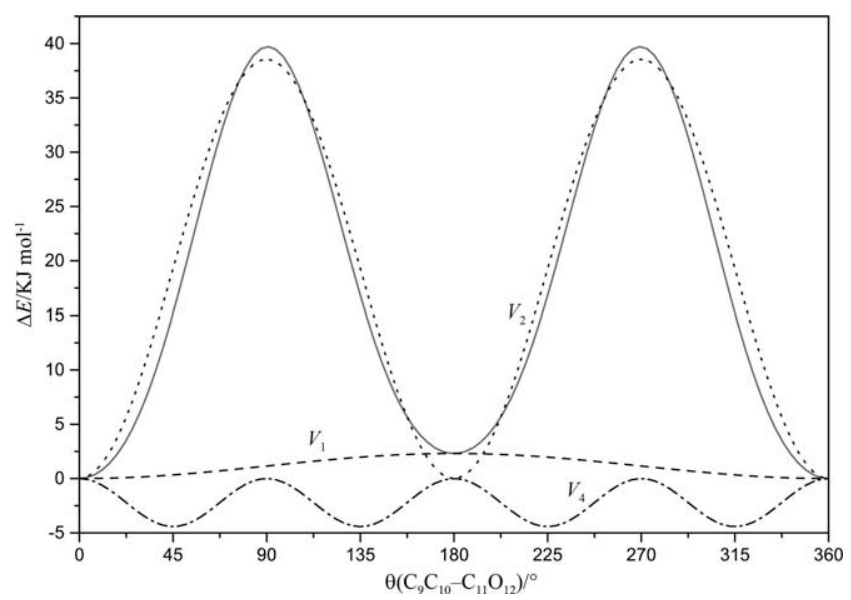

Fig. 8. Optimised conformational energy profiles (B3LYP/6-31G(d,p)), and its Fourier deconvolutions, for the internal rotation around the $\left(C_{10}-C_{11}\right)$ bond within FA. $V_{1}=2.3 \mathrm{~kJ} \mathrm{~mol}^{-1}, V_{2}=38.6 \mathrm{~kJ} \mathrm{~mol}^{-1}, V_{4}=-4.4 \mathrm{~kJ} \mathrm{~mol}^{-1}$

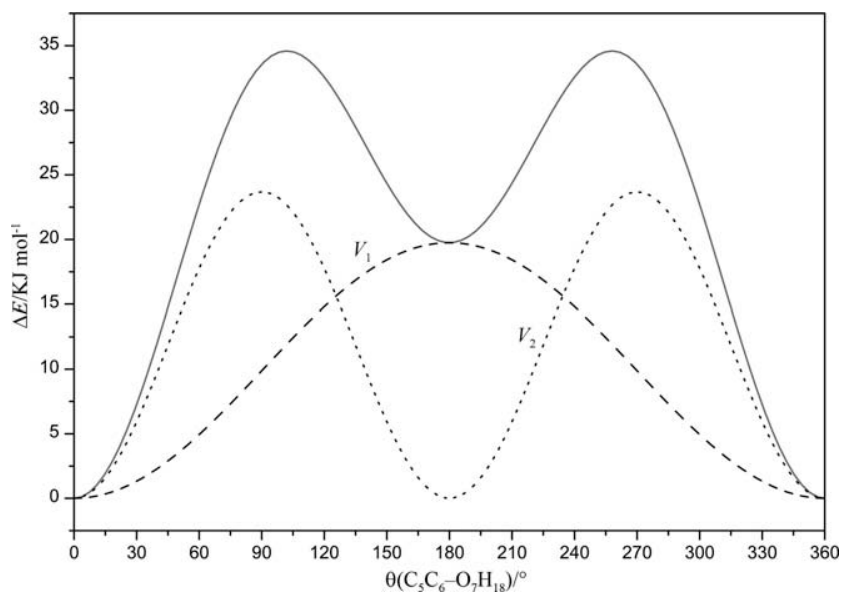

Fig. 9. Optimised conformational energy profiles (B3LYP/6-31G(d,p)), for the internal rotation around the $\left(\mathrm{C}_{6}-\mathrm{O}_{7}\right)$ bond in FA and its Fourier deconvolutions $\left(V_{1}=19.7 \mathrm{~kJ} \mathrm{~mol}^{-1}, V_{2}=23.7 \mathrm{~kJ} \mathrm{~mol}^{-1}\right)$.

sation of steric repulsions, mainly in the ester derivatives. Regarding the length of the alkyl ester group, a zigzag conformation is

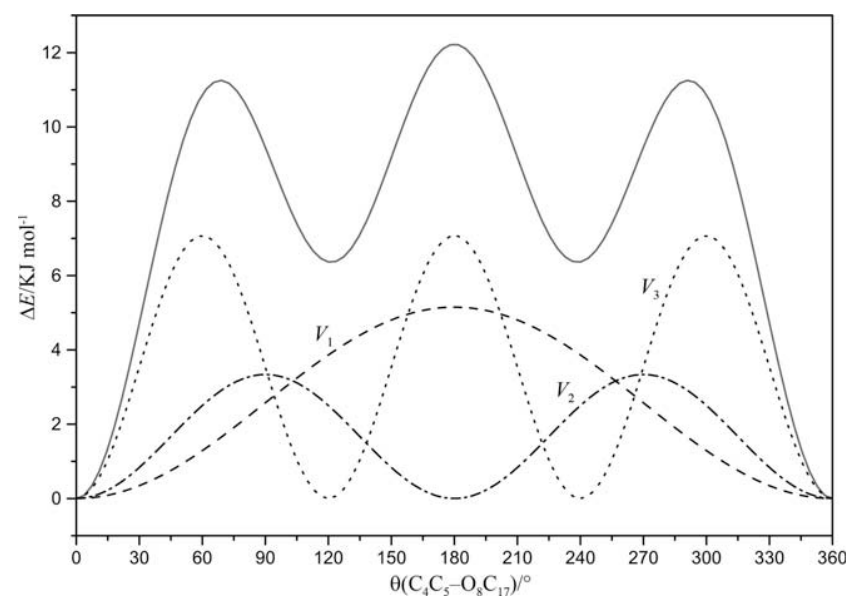

Fig. 10. Optimised conformational energy profiles (B3LYP/6-31G(d,p)) for the internal rotation around the $\left(\mathrm{C}_{5}-\mathrm{O}_{8}\right)$ bond in $\mathrm{FA}$, and its Fourier deconvolutions $\left(V_{1}=5.1 \mathrm{~kJ} \mathrm{~mol}^{-1}, V_{2}=3.3 \mathrm{~kJ} \mathrm{~mol}^{-1}, V_{3}=7.1 \mathrm{~kJ} \mathrm{~mol}^{-1}\right)$.

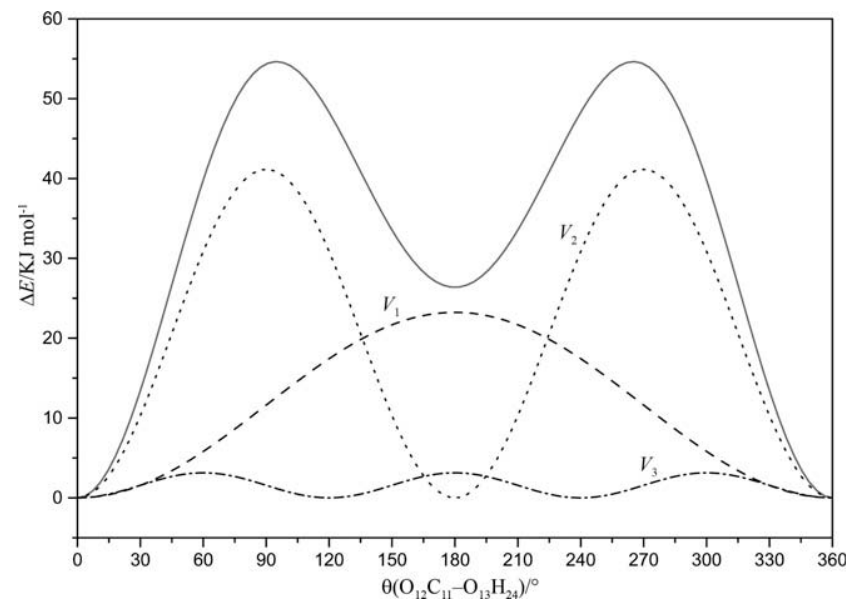

Fig. 11. Optimised conformational energy profiles (B3LYP/6-31G(d,p)) for the internal rotation around the $\left(\mathrm{C}_{11}-\mathrm{O}_{13}\right)$ bond in $\mathrm{FA}$, and its Fourier deconvolutions $\left(V_{1}=23.2 \mathrm{~kJ} \mathrm{~mol}^{-1}, V_{2}=41.2 \mathrm{~kJ} \mathrm{~mol}^{-1}, V_{3}=3.1 \mathrm{~kJ} \mathrm{~mol}^{-1}\right)$.

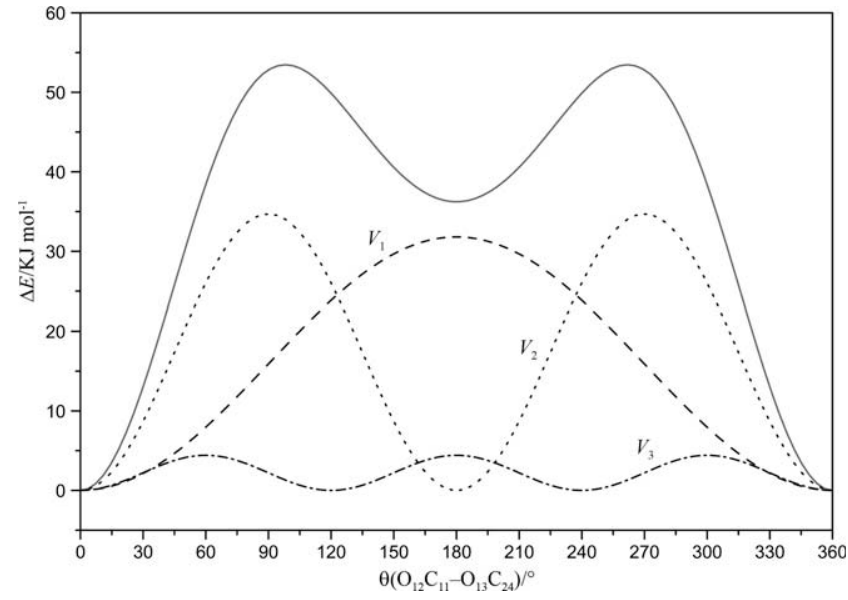

Fig. 12. Optimised conformational energy profiles (B3LYP/6-31G(d,p)) for the internal rotation around the $\left(\mathrm{C}_{11}-\mathrm{O}_{13}\right)$ bond in $\mathrm{MF}$, and its Fourier deconvolution $\left(V_{1}=31.8 \mathrm{~kJ} \mathrm{~mol}^{-1}, V_{2}=34.7 \mathrm{~kJ} \mathrm{~mol}^{-1}, V_{3}=4.4 \mathrm{~kJ} \mathrm{~mol}^{-1}\right)$.

adopted in the lowest energy structures, assuming a planar conformation relative to the remaining part of the molecule, with $\left(\mathrm{C}_{11}\right.$ - 
Table 3

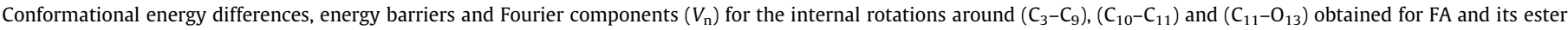
derivatives.

\begin{tabular}{|c|c|c|c|c|c|}
\hline & FA & MF & $\mathrm{EF}$ & PF & $\mathrm{BF}$ \\
\hline$C_{9}-C_{3}$ internal rotation ${ }^{a}$ & $(\mathbf{2 2} \leftrightarrow \mathbf{1})^{\mathrm{b}}$ & $(\mathbf{2} \leftrightarrow 1)$ & $(\mathbf{2} \leftrightarrow \mathbf{1})$ & $(\mathbf{2} \leftrightarrow \mathbf{1})$ & $(\mathbf{2} \leftrightarrow \mathbf{1})$ \\
\hline$\Delta E$ & 1.0 & 0.9 & 0.8 & 0.8 & 0.8 \\
\hline Rotational barrier & 29.8 & 27.9 & 27.8 & 27.8 & 27.7 \\
\hline$V_{1}$ & -0.6 & -0.5 & -0.5 & -0.4 & -0.4 \\
\hline$V_{2}$ & 28.8 & 28.0 & 28.0 & 27.8 & 27.8 \\
\hline$V_{4}$ & -4.6 & -4.5 & -4.5 & -4.4 & -4.4 \\
\hline$C_{10}-C_{11}$ internal rotation & $(\mathbf{3} \leftrightarrow \mathbf{1})$ & $(3 \leftrightarrow 1)$ & $(3 \leftrightarrow 1)$ & $(3 \leftrightarrow 1)$ & $(3 \leftrightarrow 1)$ \\
\hline$\Delta E$ & 3.1 & 3.9 & 3.7 & 3.7 & 3.7 \\
\hline Rotational barrier & 40.4 & 39.3 & 39.1 & 39.0 & 39.0 \\
\hline$V_{1}$ & 2.3 & 3.1 & 2.5 & 2.5 & 2.5 \\
\hline$V_{2}$ & 38.6 & 36.9 & 37.1 & 37.1 & 37.1 \\
\hline$V_{4}$ & -4.4 & -3.9 & -4.4 & -4.1 & -4.1 \\
\hline $\mathrm{C}_{11}-\mathrm{O}_{13}$ internal rotation & $(\mathbf{1 1} \leftrightarrow \mathbf{1})$ & $(13 \leftrightarrow 1)$ & $(13 \leftrightarrow 1)$ & $(13 \leftrightarrow 1)$ & $(13 \leftrightarrow 1)$ \\
\hline$\Delta E$ & 25.4 & 35.8 & 34.6 & 34.3 & 34.4 \\
\hline Rotational barrier & 55.4 & 53.3 & 51.6 & 51.4 & 51.5 \\
\hline$V_{1}$ & 23.2 & 31.8 & 30.6 & 30.3 & 30.3 \\
\hline$V_{2}$ & 41.2 & 34.7 & 33.7 & 33.7 & 33.8 \\
\hline$V_{3}$ & 3.1 & 4.4 & 4.1 & 4.1 & 4.1 \\
\hline
\end{tabular}

a All values are in $\mathrm{kJ} \mathrm{mol}^{-1}$

b The numbers refer to the conformers considered in each case, see Figs. 2-6.

$\left.\mathrm{O}_{13}-\mathrm{C}_{24}-\mathrm{C}_{27}\right),\left(\mathrm{O}_{13}-\mathrm{C}_{24}-\mathrm{C}_{27}-\mathrm{C}_{30}\right)$ and $\left(\mathrm{C}_{24}-\mathrm{C}_{27}-\mathrm{C}_{30}-\mathrm{C}_{33}\right)$ dihedrals equal to $180^{\circ}$ (Figs. 2-6, Tables 2 ).

As expected, the two most stable conformers of the hydroxycinnamic derivatives studied exhibit a syn conformation $\left(\theta\left(C_{9}=C_{10^{-}}\right.\right.$ $\left.\mathrm{C}_{11}=\mathrm{O}_{12}\right)=0^{\circ}$, conformers 1 and $\mathbf{2}$ ), followed by a pair of conformers with an anti conformation $\left(\theta\left(C_{9}=C_{10}-C_{11}=O_{12}\right)=180^{\circ}\right.$, conformers 3 and 4) (Figs. 2-6). The syn conformers are the most populated, at room temperature: $49-50 \%$ for 1 (the lowest energy geometry), and $34-35 \%$ for $\mathbf{2}$. As to the anti conformers, populations of $10-11 \%$ and $4-5 \%$ were obtained for 3 and $\mathbf{4}$, respectively (Supplementary material, Figs. S1-S5).

\subsection{Lateral chain orientation relative to the aromatic ring}

Rotational isomerism around $\left(C_{3}-C_{9}\right)$ gives rise to the energy minima that correspond to conformers $1\left(\theta\left(C_{2}-C_{3}-C_{9^{-}}\right.\right.$ $\left.\left.C_{10}\right)=180^{\circ}\right)$ and $2\left(\theta\left(C_{2}-C_{3}-C_{9}-C_{10}\right)=0^{\circ}\right)$ (Figs. 2-6 and Fig. 7). The best fitting was obtained by adding the cosine terms in $180^{\circ}$ $\left(V_{1}=-0.4\right.$ to $\left.-0.6 \mathrm{~kJ} \mathrm{~mol}^{-1}\right), 90^{\circ}\left(V_{2}=27.8-28.8 \mathrm{~kJ} \mathrm{~mol}^{-1}\right)$ and $45^{\circ}$ $\left(V_{4}=-4.4\right.$ to $-4.6 \mathrm{~kJ} \mathrm{~mol}^{-1}$ ) (Fig. 7, Table 3 ). This conformational behaviour is a consequence of the combination between the resonance effects between the lateral unsaturated chain and the aromatic ring, and the $\mathrm{H}_{19}-\mathrm{H}_{15} / \mathrm{H}_{16}$ and $\mathrm{H}_{20}-\mathrm{H}_{15} / \mathrm{H}_{16}$ repulsions. The conformations with lower energy values have a clear preference for planarity, the most favourable one displaying a $\left(\mathrm{C}_{2}-\mathrm{C}_{3}-\mathrm{C}_{9^{-}}\right.$ $\mathrm{C}_{10}$ ) dihedral equal to $180^{\circ}$ (the absolute minimum), which is reflected by the slightly negative value of the $V_{1}$ term. The cosine term $V_{2}$ also represents the stabilisation of these conformations, for which a maximisation of the resonance effect occurs for a $\left(C_{2}-C_{3}-C_{9}-C_{10}\right)$ dihedral equal to $180^{\circ}$ or $0^{\circ}$. The high energy values obtained for the geometries with $\left(C_{2}-C_{3}-C_{9}-C_{10}\right)$ dihedrals of $90^{\circ}$ and $270^{\circ}$ is due to a complete break in the conjugation between the vinyl group and the phenyl ring. The $V_{4}$ term reflects the steric hindrance between the vinyl $\mathrm{H}$ atoms and $\mathrm{H}_{15} / \mathrm{H}_{16}$ from the aromatic ring. The lower energy value found for a $\left(\mathrm{C}_{2}-\mathrm{C}_{3}-\mathrm{C}_{9}-\right.$ $\mathrm{C}_{10}$ ) dihedral equal to $45^{\circ}, 135^{\circ}, 225^{\circ}$ and $315^{\circ}$ are due to the minimisation of steric repulsions.

\subsection{Orientation of the carboxylic moiety}

The energy difference between the syn and the anti conformations of FA and its ester derivatives lies between 3.1 and $5.0 \mathrm{~kJ} \mathrm{~mol}^{-1}$ (Figs. 2-6). The energy barrier for the internal rotation interconverting the anti conformer $\mathbf{3}$ and the most stable syn species 4 were obtained for each compound investigated, yielding values between 39.0 and $40.4 \mathrm{~kJ} \mathrm{~mol}^{-1}$ (Fig. 8, Table 3). The energy profile for the internal rotation $\left(C_{10}-C_{11}\right)$ is identical for all the compounds under study, and the largest contribution is represented by the cosine term $V_{2}\left(38.6 \mathrm{~kJ} \mathrm{~mol}^{-1}\right.$, Fig. 8$)$, favouring the planar structures, due to a more effective resonance between the vinyl group and the carboxylic moiety. The smaller contribution of the $V_{1}$ term $\left(2.3 \mathrm{~kJ} \mathrm{~mol}^{-1}\right)$, in turn, reflects the resonance effect between the aromatic ring and the lateral carbon chain, which is energetically unfavourable for an $\left(\mathrm{C}_{9}=\mathrm{C}_{10}-\mathrm{C}_{11}=\mathrm{O}_{12}\right)$ angle of $180^{\circ}$ - anti conformer. The higher stability found for the syn geometries relative to the anti ones can be explained by the planar zigzag arrangement from the aromatic ring to the terminal hydroxyl or alkyl ester groups, which is not possible in the anti conformer.

The $V_{4}$ term $\left(-4.4 \mathrm{~kJ} \mathrm{~mol}^{-1}\right)$ favours the conformations with a $\left(\mathrm{C}_{9}=\mathrm{C}_{10}-\mathrm{C}_{11}=\mathrm{O}_{12}\right)$ dihedral equal to $\left(45^{\circ}+n 90^{\circ}\right) n=0,1,2,3$, and appears to evidence the importance of the inductive effect due to the carboxylic group (Fig. 8). In fact, this effect is transmitted through space and determined by electrostatic forces (field effect). The interconversions between $\mathrm{A} \rightarrow \mathrm{B}\left(\theta\left(\mathrm{C}_{9}=\mathrm{C}_{10}-\mathrm{C}_{11}=\mathrm{O}_{12}\right)=0^{\circ}\right.$ to $\left.4^{\circ}\right)$ and $\mathrm{C} \rightarrow \mathrm{D}\left(\theta\left(\mathrm{C}_{9}=\mathrm{C}_{10}-\mathrm{C}_{11}=\mathrm{O}_{12}\right)=180^{\circ}-135^{\circ}\right)$ through the $\left(\mathrm{C}_{10}-\mathrm{C}_{11}\right)$ internal rotation (Fig. 13) cause a monodirectional redistribution of the electron density, respectively: $\mathrm{O}_{12}(-0.495 \rightarrow-0.473 ;-0.493 \rightarrow$ $-0.474), \mathrm{O}_{13}(-0.507 \rightarrow-0.487 ;-0.509 \rightarrow-0.484), \mathrm{C}_{10}(-0.147 \rightarrow$ $-0.123 ;-0.151 \rightarrow-0.131), \mathrm{C}_{11}(0.561 \rightarrow 0.515 ; 0.571 \rightarrow 0.524), \mathrm{H}_{19}$ $(0.121 \rightarrow 0.112 ; 0.118 \rightarrow 0.108)$, and $\mathrm{H}_{20}(0.094 \rightarrow 0.101 ; 0.097 \rightarrow$ 0.104 ). No changes were observed in the charge on $C_{9}$ (directly linked to the ring) and on the terminal $\mathrm{H}_{24}$ atoms. Consequently, the stability of the conformations displaying these particular dihedrals was ascribed to a weak electrostatic interaction between $\mathrm{H}_{19}$ and/or $\mathrm{H}_{20}$ and the oxygen lone pairs. This stabilisation is responsible for a widening of the total rotational energy profile (Fig. 8). For the other geometries considered, corresponding to anti and syn conformers, respectively, it may be assumed that a repulsive interaction occurring between the two oxygen lone pairs and the $\pi$-electrons of the $(C=C)$ bond lead to a destabilisation, that is more significant for the planar structures.

\subsection{Relative orientation of the hydroxyl and methoxyl groups}

Conformers displaying $\left(\mathrm{C}_{5}-\mathrm{C}_{6}-\mathrm{O}_{7}-\mathrm{H}_{18}\right)$ and $\left(\mathrm{C}_{4}-\mathrm{C}_{5}-\mathrm{O}_{8}-\mathrm{C}_{17}\right)$ dihedral angles equal to $180^{\circ}$ and $0^{\circ}$, respectively, were found to 
a

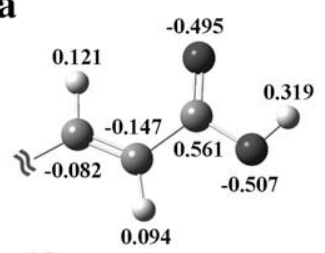

$\theta\left(\mathbf{O}_{12}-\mathbf{C}_{11}-\mathbf{C}_{20}-\mathbf{C}_{9}\right)=0^{\circ}$

c

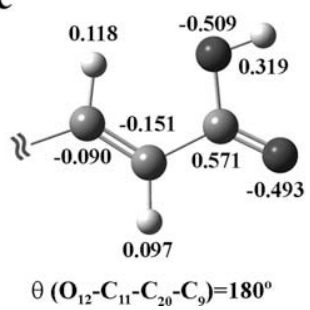

b

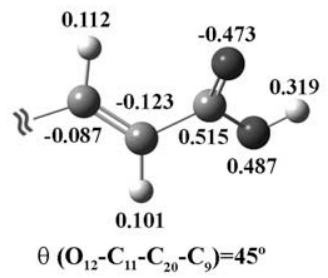

d

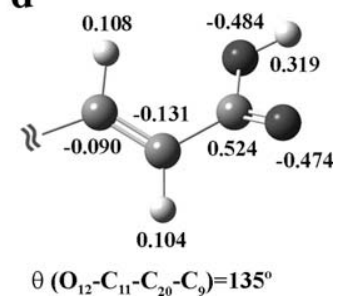

Fig. 13. Schematic representation of the orientations considered for the carboxylic moiety of FA (B3LYP/6-31G(d,p)): $\theta\left(C_{9}-C_{10}-C_{11}-O_{12}\right)=0^{\circ}$ (syn) (a), 45 (b), $180^{\circ}$ (anti) $(\mathrm{c}), 135^{\circ}$ (d). (The atomic Mulliken charges are represented).

be quite energetic (e.g. conformer 1 vs. 5, Figs. 2-6), since stabilising intramolecular hydrogen bond between $(\mathrm{O}) \mathrm{H}$ and $\mathrm{O}\left(\mathrm{CH}_{3}\right)$ cannot occur and there is a considerable $\mathrm{H}_{18}-\mathrm{H}_{14}$ steric repulsion $\left(d=229 \mathrm{pm}\right.$ for geometries with $\theta\left(\mathrm{C}_{2}-\mathrm{C}_{3}-\mathrm{C}_{9}-\mathrm{C}_{10}\right)=180^{\circ}$, e.g. conformer $5 ; d=228 \mathrm{pm}$ for conformers with $\theta\left(C_{2}-C_{3}-C_{9}-C_{10}\right)=0^{\circ}$, e.g. conformer 6) (Figs. 2-6). In addition, for those conformations displaying an $\mathrm{OH}$ group coplanar with the aromatic ring, this $\mathrm{H}-$ $\mathrm{H}$ steric hindrance was found to induce a widening of the $\left(\mathrm{C}_{1}-\right.$ $\mathrm{C}_{6}-\mathrm{O}_{7}$ ) angle ( $\alpha=120.5^{\circ}$ vs. $123.6^{\circ}$, e.g. conformer 1 vs. 5, Figs. $\left.2-6\right)$.

The minimum energy geometries resulting from a dihedral $\left(\mathrm{C}_{5}\right.$ $\mathrm{C}_{6}-\mathrm{O}_{7}-\mathrm{H}_{18}$ ) equal $180^{\circ}$ or $0^{\circ}$, have conformational relative energies between 18.3 and $19.4 \mathrm{~kJ} \mathrm{~mol}^{-1}$ (e.g. conformer 2 vs. 6, Figs. 2-6). A Fourier analysis of the $\left(\mathrm{C}_{6}-\mathrm{O}_{7}\right)$ internal rotation, associated to the orientation of the phenolic hydroxyl group relative to the ring, reflects a clear preference for planarity, owing to the predominant stabilising contribution represented by the cosine term $V_{2}$ $\left(23.7 \mathrm{~kJ} \mathrm{~mol}^{-1}\right.$ ) (Fig. 9). The positive contribution of the $V_{1}$ term $\left(19.7 \mathrm{~kJ} \mathrm{~mol}^{-1}\right)$ also favours a $\left(C_{4}-C_{3}-C_{9}-C_{10}\right)$ dihedral of $0^{\circ}$, the maximum at $180^{\circ}$ being the result of a destabilising steric hindrance between the hydroxyl $\mathrm{H}_{18}$ and the aromatic $\mathrm{H}_{14}$ atoms (Figs. 2-6 and Fig. 9). Therefore for all the compounds studied, the stability of these conformers is mainly due to the formation of intramolecular $(\mathrm{O}) \mathrm{H} \cdots \mathrm{O}\left(\mathrm{CH}_{3}\right)$ interactions, and an effective $\pi$ electron delocalisation, favoured for planar geometries.

Minimum energy conformations displaying $\left(\mathrm{C}_{4}-\mathrm{C}_{5}-\mathrm{O}_{8}-\mathrm{C}_{17}\right)$ and $\left(\mathrm{C}_{5}-\mathrm{C}_{6}-\mathrm{O}_{7}-\mathrm{H}_{18}\right)$ dihedrals equal to $120^{\circ}$ and $180^{\circ}$, respectively, were also found. These non-planar geometries (e.g. conformer $\mathbf{8}$, Figs. 2-6) were verified to be less energetic as compared to the ones with a $\left(\mathrm{C}_{4}-\mathrm{C}_{5}-\mathrm{O}_{8}-\mathrm{C}_{17}\right)$ angle of $180^{\circ}$, for which the $\mathrm{O}_{7}$ atom lies equidistant to both $\mathrm{H}_{21}$ and $\mathrm{H}_{22}(d=251 \mathrm{pm})$, yielding a bifurcated weak hydrogen bond. In order to better understand these results, a scanning of the rotation around the $\left(\mathrm{C}_{5}-\mathrm{O}_{8}\right)$ bond and the corresponding Fourier deconvolutions were performed for FA (Fig. 10). From the analysis of this Fourier profile it was verified that the absolute maximum, occurring for $\left(\mathrm{C}_{4}-\mathrm{C}_{5}-\mathrm{O}_{8}-\mathrm{C}_{17}\right)$ equal to $180^{\circ}$, comprises contributions from $V_{1}\left(5.1 \mathrm{~kJ} \mathrm{~mol}^{-1}\right)$ and $V_{3}$ $\left(7.1 \mathrm{~kJ} \mathrm{~mol}^{-1}\right)$, reflecting the steric repulsion between $\mathrm{H}_{14}$ and (O) $\mathrm{H}_{18}$ and the formation of a $\left(\mathrm{O}_{7} \cdots \mathrm{H}_{21 / 22}\right)$ hydrogen bond, respectively. Furthermore, the most stable structure arises for $\left(\mathrm{C}_{4}-\mathrm{C}_{5}-\right.$ $\mathrm{O}_{8}-\mathrm{C}_{17}$ ) equal to $0^{\circ}$ (conformer $\mathbf{5}$ ), evidencing a preference for planarity which allows an extensive conjugation within the molecule, the term $V_{2}\left(3.3 \mathrm{~kJ} \mathrm{~mol}^{-1}\right)$ being the main responsible for stabilisa-

tion of these conformations. In turn, the geometrical preferences for the local minimum with a $\left(\mathrm{C}_{4}-\mathrm{C}_{5}-\mathrm{O}_{8}-\mathrm{C}_{17}\right)$ dihedral of $120^{\circ}$ (e.g. conformer 8, Figs. 2-6) are due to the formation of a directional stabilising hydrogen bond $\left(d\left(\mathrm{O}_{7} \cdots \mathrm{H}_{21}\right)=238 / 9\right.$ pm, Figs. 26 ), which is represented by the cosine term $V_{3}$ (Fig. 10).

\section{5. s-cis and s-trans conformations}

The conformers obtained for ferulic acid and its ester derivatives displaying either the $\mathrm{H}_{24}$ atom or the ester chain in an s-trans orientation relative to the carbonyl oxygen $\left(\theta\left(\mathrm{O}_{12}-\mathrm{C}_{11}-\mathrm{O}_{13}-\mathrm{H}_{24}\right)\right.$ $\left.C_{24}\right)=180^{\circ}$ ) were found to give rise to highly energetic species when compared to the correspondent s-cis conformations (Supplementary material, Figs. S1-S5). This destabilisation is mainly due to the occurrence of steric repulsions between the two nearest hydrogen atoms of the vinyl group and the hydrogen of the carboxylic acid, or the hydrogen atoms of the alkyl ester moiety, (e.g. FA 1 vs. FA 11, Fig. 2; conformer 1 vs. 13, for the ferulates, Figs. 3-6). Considering the Fourier components of the corresponding potential-energy profiles, this highly destabilising effect is represented by the cosine term $V_{1}\left(23.2 \mathrm{~kJ} \mathrm{~mol}^{-1}\right.$ for FA, Fig. $11 ; 30.3-$ $31.8 \mathrm{~kJ} \mathrm{~mol}^{-1}$ for the ferulates, Fig. 12 and Table 3), being predominant for the esters, due to the presence of the bulkier alkyl groups. Regarding the s-cis conformers, stabilisation is mainly attributed to resonance effects, mostly comprised in the term $V_{2}\left(41.2 \mathrm{~kJ} \mathrm{~mol}^{-1}\right.$ for FA; $33.7-34.7 \mathrm{~kJ} \mathrm{~mol}^{-1}$ for the ferulates, Figs. 11 and 12 , Table 3 ), being more relevant for the acid as compared to its ester counterparts. In order to attain a more effective $\pi$-electron delocalisation, the $\left(\mathrm{C}_{10}-\mathrm{C}_{11}\right)$ and $\left(\mathrm{C}_{11}-\mathrm{O}_{13}\right)$ bonds become slightly shorter when compared to the corresponding s-trans conformers. Moreover, when considering the s-cis to s-trans conversion the negative inductive effect of the electron withdrawal $\mathrm{COOH}$ or $\mathrm{COO}\left(\mathrm{CH}_{2}\right)_{n}\left(\mathrm{CH}_{3}\right)$ groups must also be taken into account, and this is reflected by the less energetic term $V_{3}\left(3.1 \mathrm{~kJ} \mathrm{~mol}^{-1}\right.$ for FA; 4.1-4.4 $\mathrm{kJ} \mathrm{mol}^{-1}$ for the ferulates, Figs. 11 and 12, Table 3). This is less significant for the s-trans conformations than for the s-cis ones, and an electrical charge redistribution along the $\left(\mathrm{C}_{9}-\mathrm{C}_{10^{-}}\right.$ $\left.\mathrm{C}_{11}-\mathrm{O}_{12}-\mathrm{O}_{13}-\mathrm{H}_{24} / \mathrm{C}_{24}\right)$ skeleton occurs upon an s-trans to s-cis rearrangement (Supplementary material, Fig. S6).

The highest energy conformers obtained for these systems result from a combination of a $\left(\mathrm{O}_{13}-\mathrm{C}_{11}-\mathrm{C}_{10}-\mathrm{C}_{9}\right)$ dihedral equal to $180^{\circ}$ (s-trans geometries), and an out-of-plane $\mathrm{H}_{24}$ atom (in the acid) or alkyl ester chain (e.g. conformer 20, Figs. 2-6).

\subsection{General considerations}

Firstly, it was verified that for all the presently calculated conformers a change in the $\left(C_{4}-C_{3}-C_{9}-C_{10}\right)$ dihedral from $0^{\circ}$ to $180^{\circ}$ induces a small difference in their overall conformational energy $\left(\Delta E=0.4-2.1 \mathrm{~kJ} \mathrm{~mol}^{-1}\right.$, e.g. FA 1 vs. FA 2; MF 7 vs. MF 9; EF 7 vs. EF 10; PF 3 vs. PF 4; BF 11 vs. BF 12), this geometrical parameter thus being the one that less contributes to the destabilisation of the $\pi$-conjugated system. Also, the energetic difference between the syn and anti conformers, which are defined by the $\left(\mathrm{C}_{9}=\mathrm{C}_{10^{-}}\right.$ $\mathrm{C}_{11}=\mathrm{O}_{12}$ ) dihedral, lies between 3.1 and $5.0 \mathrm{~kJ} \mathrm{~mol}^{-1}$ (e.g. FA 1 vs. FA 3, MF 2 vs. MF 4, EF 5 vs. EF 7, PF 9 vs. PF 12 and BF 6 vs. BF 10) (Figs. 2-6).

Regarding the orientation of the hydroxyl and methoxyl ring substituents, the most favourable ones correspond to $\left(\mathrm{C}_{5}-\mathrm{C}_{6}-\mathrm{O}_{7}-\right.$ $\left.\mathrm{H}_{18}\right)$ and $\left(\mathrm{C}_{4}-\mathrm{C}_{5}-\mathrm{O}_{8}-\mathrm{C}_{17}\right)$ equal to $0^{\circ}$, since this allows the formation of a stabilising medium strength intramolecular $(\mathrm{O}) \mathrm{H} \cdots \mathrm{O}\left(\mathrm{CH}_{3}\right)$ interaction, contributing to a stability increase of these hydroxycinnamic derivatives (e.g. FA 1, MF 2, EF 5, PF 9 and BF 1, Figs. 2$6)$. The internal rotation defined by the $\left(\mathrm{C}_{5}-\mathrm{C}_{6}-\mathrm{O}_{7}-\mathrm{H}_{18}\right)$ dihedral $\left(0^{\circ}-180^{\circ}\right)$ yielded conformers with a similar relative energy $\left(\Delta E=18.3-19.4 \mathrm{~kJ} \mathrm{~mol}^{-1}\right)$. The ones displaying a dihedral equal 
to $180^{\circ}$ are favoured and exhibit an $\mathrm{OH}$ group coplanar with the ring and a wider $\left(\mathrm{C}_{1}-\mathrm{C}_{6}-\mathrm{O}_{7}\right)$ angle relative to the ones displaying a dihedral equal to $0^{\circ}$, as a result of the repulsive effects between $\mathrm{H}_{18}$ and the aromatic $\mathrm{H}_{14}$ (e.g. FA 1 vs. FA 5, MF 2 vs. MF 6, EF 3 vs. EF 7, PF 4 vs. PF 10 and BF 13 vs. BF 16, Figs. 2-6). In addition, the energy minima with $\left(\mathrm{C}_{5}-\mathrm{C}_{6}-\mathrm{O}_{7}-\mathrm{H}_{18}\right)$ and $\left(\mathrm{C}_{4}-\mathrm{C}_{5}-\mathrm{O}_{8}-\mathrm{C}_{17}\right)$ equal to $180^{\circ}$ and $120^{\circ}$, respectively, were found to display the most unfavourable orientations of the ring substituent. The main factors responsible for this destabilisation are the deviation from planarity and the steric hindrance between $(\mathrm{C}) \mathrm{H}_{14}$ and $(\mathrm{O}) \mathrm{H}_{18}$. In turn, these conformers are mainly stabilised by an $\mathrm{H}$-bond interaction $\left(d\left(\mathrm{O}_{7} \cdots \mathrm{H}_{21}\right)=238 / 9 \mathrm{pm}\right.$, Figs. $\left.2-6\right)$ which was found to be stronger than the bifurcated weak $\mathrm{H}$-bond between $\mathrm{O}_{7}$ and the methoxyl $\mathrm{H}_{21}$ and $\mathrm{H}_{22}$ atoms $\left(d\left(\mathrm{O}_{7} \cdots \mathrm{H}_{21 / 22}\right)=251 \mathrm{pm}\right)$ that would occur for $\left(\mathrm{C}_{4}-\mathrm{C}_{5}-\mathrm{O}_{8}-\mathrm{C}_{17}\right)$ equal to $180^{\circ}$. Therefore, these geometries give rise to an energy difference between 3.8 and $5.2 \mathrm{~kJ} \mathrm{~mol}^{-1}$ relative to the ones with $\left(\mathrm{C}_{5}-\mathrm{C}_{6}-\mathrm{O}_{7}-\mathrm{H}_{18}\right)$ and $\left(\mathrm{C}_{4}-\mathrm{C}_{5}-\mathrm{O}_{8}-\mathrm{C}_{17}\right)$ equal to $180^{\circ}$ and $0^{\circ}$, respectively (e.g. FA 5 vs. FA 8, MF 6 vs. MF 9, EF 7 vs. EF 11, PF 10 vs. PF 12 and BF 16 vs. BF 18, Figs. 2-6).

Furthermore, it may be concluded for all the compounds studied that a $\left(\mathrm{O}_{12}-\mathrm{C}_{11}-\mathrm{O}_{13}-\mathrm{H}_{24} / \mathrm{C}_{24}\right)$ dihedral equal to $0^{\circ}$, corresponding to s-trans conformations, is the most destabilising parameter. The high energy values obtained for these conformers arise from a strong steric hindrance between $\mathrm{H}_{19} / \mathrm{H}_{20}$ and $\mathrm{H}_{24}$ (for FA) or the $\mathrm{H}$ atoms from the ester alkyl moiety. Moreover, resonance and inductive effects should be considered for the s-cis to s-trans interconversion, as a result of the $\left(\mathrm{C}_{11}-\mathrm{O}_{13}\right)$ rotation, the former being more pronounced for the acid. The (s-trans)-(s-cis) energy difference was calculated to be between 24.8 and $25.4 \mathrm{~kJ} \mathrm{~mol}^{-1}$ for FA (e.g. FA 1 vs. FA 11) and between 33.6 and $36.2 \mathrm{~kJ} \mathrm{~mol}^{-1}$ for the ferulates (e.g. MF 2 vs. MF 13, EF 3 vs. EF 15, PF 6 vs. PF 16, and BF 9 vs. BF 18, Figs. 2-6). Finally, the anti geometries displaying an s-trans orientation of the COOR group were found to give rise to saddle points in the potential-energy surface, except when the COOR group deviates from planarity, in which case highly energetic conformers were obtained ( $\Delta E$ higher than $70 \mathrm{~kJ} \mathrm{~mol}^{-1}$, Supplementary material, Figs. S1-S5; e.g. FA 19, MF 17, EF 21, PF 20 and BF 19, Figs. 2-6).

\section{Conclusions}

In general, the structural preferences of FA and its alkyl ester derivatives were found to be identical. The most stable molecular structures obtained for this cinnamic acid and the esters investigated display the hydroxyl and methoxyl groups coplanar to the aromatic ring $\left(\theta\left(\mathrm{C}_{5}-\mathrm{C}_{6}-\mathrm{O}_{7}-\mathrm{H}_{18}\right) /\left(\mathrm{C}_{4}-\mathrm{C}_{5}-\mathrm{O}_{8}-\mathrm{C}_{17}\right)=0^{\circ}\right.$, presenting either a $\left(C_{2}-C_{3}-C_{9}-C_{10}\right)$ dihedral equal to $0^{\circ}$ and $180^{\circ}$ or a syn or anti conformation, coupled to an s-cis conformation defined by the $\left(\mathrm{O}_{12}-\mathrm{C}_{11}-\mathrm{O}_{13}-\mathrm{H}_{24} / \mathrm{C}_{24}\right)$ dihedral. Concerning the length of the alkyl ester group, a zigzag conformation is adopted, coplanar with the cinnamic moiety. Therefore, the conformational behaviour of the resulting planar structures seems to be mainly determined by a balance between the stabilising resonance and hydrogen bonding effects and the destabilising non-bonding repulsions.

The present results are in perfect agreement with the ones obtained for cinnamic acid [43] and its analogues, such as hydroxycinnamic acid and its ester or amide derivatives [44-49]. In particular, the conformational preferences of naturally occurring hydroxycinnamic acids differing in the ring substitution pattern is strongly dependent on the number, type and relative orientation of these substituents (hydroxyl and/or methoxyl groups). Actually, studies carried out for $p$-coumaric (4-hydroxycinnamic acid), caffeic (3,4-dihydroxycinnamic acid) [47], ferulic (4-hydroxy-3-methoxycinnamic acid), sinapic (4-hydroxy-3,5-dimethoxycinnamic acid) and 3,4,5-trihydroxycinnamic acids [48] reveal some impor- tant differences in these geometrical parameters which may influence their biological (e.g. antioxidant) activity [50-56]. The most stable conformers found for mono- and tri-substituted cinnamic acids display an identical orientation of the hydroxyl/methoxyl groups (except when a strong steric hindrance is involved, namely in sinapic acid) coupled to a syn conformation relative to the carbonyl group. In turn, the disubstituted ones present the same orientation of the ring hydroxyl/methoxyl groups, but opposed relative to the carbonyl group (anti). However, both geometries should be taken into consideration for structural, chemical and biological studies regarding hydroxycinnamic acids since they are the most populated ones at room temperature. In di- and tri substituted compounds a stabilising intramolecular $\mathrm{H}$-bond is formed, which is known to be energetically favourable in this kind of phenolic systems [44-49,57], and is therefore essential for the interpretation of their structure-activity relationships (SAR's).

From the analysis of the conformational results reported for cinnamic acids and their ester derivatives it can be concluded that the additional degrees of freedom introduced by esterification are mainly reflected in the internal rotation around the $\left(\mathrm{C}_{11}-\mathrm{O}_{13}\right)$ bond, defining either an s-cis or an s-trans conformation, which showed to be the most destabilising factor for these phenolic systems. As expected, esterification affects mainly the energy barrier corresponding to the $(\mathrm{O}=) \mathrm{C}-\mathrm{OR}$ internal rotation. Furthermore, the deviations from planarity of the $C O O R$ group $(\mathrm{R}=\mathrm{H}$ or $\left.\left(\mathrm{CHR}_{2}\right)_{n}\left(\mathrm{CH}_{3}\right), n=0,1,2,3\right)$, were only found for the s-trans conformers, as a consequence of a strong steric hindrance. Also, regarding the hydroxycinnamates, it can be concluded that their overall stability is influenced by the same factors, presenting similar structural preferences.

This information is essential for an accurate interpretation of numerous biochemical functions known to these compounds, namely antioxidant and antineoplasic properties, leading to the establishment of structure-property-activity relationships (SPAR's) and therefore allowing to develop new and more effective chemopreventive/chemotherapeutic phenolic agents.

\section{Acknowledgements}

The authors acknowledge financial support from the Portuguese Foundation for Science and Technology - Project POCI/QUI/55631/ 2004 (co-financed by the European Community fund FEDER). RC acknowledges FCT - PhD fellowship SFRH/BD/16520/2004.

\section{Appendix A. Supplementary data}

Supplementary data associated with this article can be found, in the online version, at doi:10.1016/j.theochem.2009.07.032.

\section{References}

[1] A. Fardet, E. Rock, C. Remesy, J. Cereal Sci. 48 (2008) 258.

[2] C.A. Gomes, T.G. de Cruz, J.L. Andrade, N. Milhazes, F. Borges, M.P.M. Marques, J. Med. Chem. 46 (2003) 5395.

[3] M.A. Soobrattee, V.S. Neergheen, A. Luximon-Ramma, O.I. Aruoma, T. Bahorun, Mutat. Res. Fundam. Mol. Mech. Mutagen. 579 (2005) 200.

[4] E.H. Jung, S.R. Kim, I.K. Hwang, T.Y. Ha, J. Agric. Food Chem. 55 (2007) 9800

[5] S. Adisakwattana, P. Moonsan, S. Yibchok-Anun, J. Agric. Food Chem. 56 (2008) 7838.

[6] B.H. Wang, J.P. Ou-Yang, Cardiovasc. Drug Rev. 23 (2005) 161.

[7] G. Scapagnini, D.A. Butterfield, C. Colombrita, R. Sultana, A. Pascale, V. Calabrese, Antioxid. Redox Signal. 6 (2004) 811.

[8] J. Kanski, M. Aksenova, A. Stoyanova, D.A. Butterfield, J. Nutr. Biochem. 13 (2002) 273.

[9] L. Poquet, M.N. Clifford, G. Williamson, Arch. Biochem. Biophys. 476 (2008) 196.

[10] Y.J. Surh, H.K. Na, Genes Nutr. 2 (2008) 313.

[11] J.J. Chen, P.H. Chen, C.H. Liao, S.Y. Huang, I.S. Chen, J. Nat. Prod. 70 (2007) 1444.

[12] M.P.M. Marques, F. Borges, J. Sousa, R. Calheiros, J. Garrido, A. Gaspar, F. Antunes, C. Diniz, P. Fresco, Lett. Drug Des. Discov. 3 (2006) 316. 
[13] A. Duvoix, R. Blasius, S. Delhalle, M. Schnekenburger, F. Morceau, E. Henry, M. Dicato, M. Diederich, Cancer Lett. 223 (2005) 181.

[14] P.M. Kris-Etherton, K.D. Hecker, A. Bonanome, S.M. Coval, A.E. Binkoski, K.F. Hilpert, A.E. Griel, T.D. Etherton, Am. J. Med. 113 (2002) 71

[15] A. Murakami, Y. Nakamura, K. Koshimizu, D. Takahashi, K. Matsumoto, K. Hagihara, H. Taniguchi, E. Nomura, A. Hosoda, T. Tsuno, Y. Maruta, H.W. Kim, K. Kawabata, H. Ohigashi, Cancer Lett. 180 (2002) 121.

[16] T. Finkel, N.J. Holbrook, Nature 408 (2000) 239.

[17] G.T. Wondrak, C.M. Cabello, N.F. Villeneuve, S. Zhang, S. Ley, Y.J. Li, Z. Sun, D.D. Zhang, Free Radic. Biol. Med. 45 (2008) 385.

[18] S. Itagaki, T. Kurokawa, C. Nakata, Y. Saito, S. Oikawa, M. Kobayashi, T. Hirano, K. Iseki, Food Chem. 114 (2009) 466

[19] N.R. Prasad, S. Ramachandran, K.V. Pugalendi, V.P. Menon, Nutr. Res. 27 (2007) 559.

[20] P.A. Kroon, G. Williamson, J. Sci. Food Agric. 79 (1999) 355.

[21] E. Balogun, M. Hoque, P.F. Gong, E. Killeen, C.J. Green, R. Foresti, J. Alam, R Motterlini, Biochem. J. 371 (2003) 887

[22] V. Calabrese, S. Calafato, E. Puleo, C. Cornelius, M. Sapienza, P. Morganti, C. Mancuso, Clin. Dermatol. 26 (2008) 358.

[23] R.T. Feng, Y.J. Lu, L.L. Bowman, Y. Qian, V. Castranova, M. Ding, J. Biol. Chem. 280 (2005) 27888.

[24] Y.Z. Hou, J. Yang, G.R. Zhao, Y.J. Yuan, J. Cell. Biochem. 93 (2004) 1203.

[25] A.Y. Issa, S.R. Volate, M.J. Wargovich, J. Food Compos. Anal. 19 (2006) 405

[26] C.K. Andreadi, L.M. Howells, P.A. Atherfold, M.M. Manson, Mol. Pharmacol. 69 (2006) 1033.

[27] M.J. Frisch, G.W. Trucks, H.B. Schlegel, G.E. Scuseria, M.A. Robb, J.R. Cheeseman, J.A.J. Montgomery, T. Vreven, K.N. Kudin, J.C. Burant, M.J. Millam, S.S. Iyengar, J. Tomasi, V. Barone, B. Mennucci, M. Cossi, G. Scalmani, N. Rega, G.A. Petersson, H. Nakatsuji, M. Hada, M. Ehara, K. Toyota, R. Fukuda, J. Hasegawa, M. Ishida, T. Nakajima, Y. Honda, O. Kitao, H. Nakai, M. Klene, X. Li, J.E. Knox, H.P. Hratchian, J.B. Cross, C. Adamo, J. Jaramillo, R. Gomperts, R.E. Stratmann, O. Yazyev, A.J. Austin, R. Cammi, C. Pomelli, J.W. Ochterski, P.Y. Ayala, K. Morokuma, G.A. Voth, P. Salvador, J.J. Dannenberg, V.G. Zakrzewski, S. Dapprich, A.D. Daniels, M.C. Strain, O. Farkas, D.K. Malick, A.D. Rabuck, K. Raghavachari, J.B. Foresman, J.V. Ortiz, Q. Cui, A.G. Baboul, S. Clifford, J. Cioslowski, B.B. Stefanov, G. Liu, A. Liashenko, P. Piskorz, I. Komaromi, R.L. Martin, D.J. Fox, T. Keith, M.A. AlLaham, C.Y. Peng, A. Nanayakkara, M. Challacombe, P.M.W. Gill, B. Johnson, W. Chen, M.W. Wong, C. Gonzalez, J.A. Pople, in: Gaussian 03, Revision B. 04, Gaussian, Ed., Pittsburgh, 2003.

[28] GaussView 3.0, Gaussian, I.C.O.P., Ed., Pittsburgh, PA 15106, USA, 2003.
[29] C.T. Lee, W.T. Yang, R.G. Parr, Phys. Rev. B 37 (1988) 785

30] B. Miehlich, A. Savin, H. Stoll, H. Preuss, Chem. Phys. Lett. 157 (1989) 200

31] A.D. Becke, Phys. Rev. A 38 (1988) 3098.

[32] A.D. Becke, J. Chem. Phys. 98 (1993) 5648.

[33] P.C. Harihara, J.A. Pople, Theor. Chim. Acta 28 (1973) 213

[34] M.J. Frisch, J.A. Pople, J.S. Binkley, J. Chem. Phys. 80 (1984) 3265

[35] G.A. Petersson, A. Bennett, T.G. Tensfeldt, M.A. Allaham, W.A. Shirley, J Mantzaris, J. Chem. Phys. 89 (1988) 2193.

36] C.Y. Peng, P.Y. Ayala, H.B. Schlegel, M.J. Frisch, J. Comput. Chem. 17 (1996) 49

[37] L. Radom, J.A. Pople, W.J. Hehre, J. Am. Chem. Soc. 94 (1972) 2371

[38] L.A.E. Batista de Carvalho, A.M. Amorim da Costa, J.J.C. Teixeira-Dias, J. Mol. Struct. (THEOCHEM) 205 (1990) 327.

[39] M. Nethaji, V. Pattabhi, G.R. Desiraju, Acta Crystallogr. C 44 (1988) 275

[40] A.J. Horsewill, A. Aibout, J. Phys. Condens. Matter 1 (1989) 9609.

[41] J.H. Lii, J. Phys. Chem. A 106 (2002) 8667.

[42] I. Wolfs, H.O. Desseyn, J. Mol. Struct. (THEOCHEM) 360 (1996) 81.

[43] M.N. Nolasco, A.M. Amado, P.J.A. Ribeiro-Claro, J. Raman Spectrosc. 40 (2008) 394.

[44] R. Calheiros, N.F.L. Machado, S.M. Fiuza, A. Gaspar, J. Garrido, N. Milhazes, F Borges, M.P.M. Marques, J. Raman Spectroc. 39 (2008) 95.

[45] N.F.L. Machado, R. Calheiros, S.M. Fiuza, F. Borges, A. Gaspar, J. Garrido, M.P. Marques, J. Mol. Model. 13 (2007) 865.

[46] J.B. Sousa, R. Calheiros, V. Rio, F. Borges, M.M. Marques, J. Mol. Struct. 783 (2006) 122

[47] E. VanBesien, M.P.M. Marques, J. Mol. Struct.: THEOCHEM 625 (2003) 265.

[48] S.M. Fiuza, E. Van Besien, N. Milhazes, F. Borges, M.P.M. Marques, J. Mol. Struct. 693 (2004) 103.

[49] D.A. Rincon, E.E. Daza, M. Cordeiro, J. Mol. Struct.: THEOCHEM 804 (2007) 57

[50] C. Siquet, F. Paiva-Martins, J. Lima, S. Reis, F. Borges, Free Radic. Res. 40 (2006) 433.

[51] N. Nenadis, H.Y. Zhang, M.Z. Tsimidou, J. Agric. Food Chem. 51 (2003) 1874.

[52] A. vonGadow, E. Joubert, C.F. Hansmann, J. Agric. Food Chem. 45 (1997) 632.

[53] M. Karamac, A. Bucinski, R.B. Pegg, R. Amarowicz, Czech. J. Food Sci. 23 (2005) 64.

[54] H. Kikuzaki, M. Hisamoto, K. Hirose, K. Akiyama, H. Taniguchi, J. Agric. Food Chem. 50 (2002) 2161

[55] F.A.M. Silva, F. Borges, C. Guimaraes, J. Lima, C. Matos, S. Reis, J. Agric. Food Chem. 48 (2000) 2122

[56] M. Karamac, A. Kosiñska, R.B. Pegg, Pol. J. Food Nutr. Sci. 14/55 (2005) 165

[57] M.I. de Heer, H.G. Korth, P. Mulder, J. Org. Chem. 64 (1999) 6969. 